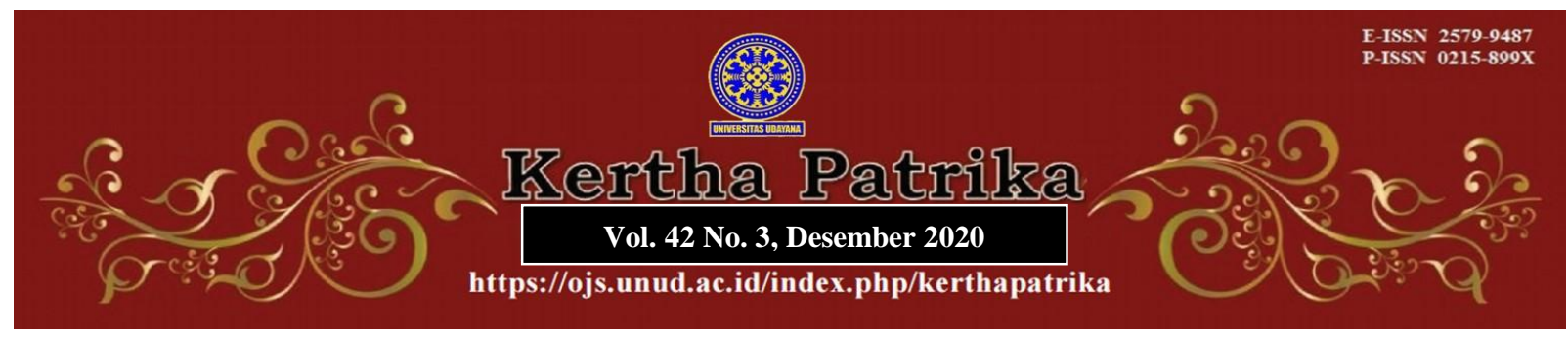

\title{
Reformulasi Delik Ideologi dalam Perspektif Pembaruan Hukum Pidana Indonesia
}

\section{Yaris Adhial Fajrin, ${ }^{1}$ Ach Faisol Triwijaya, ${ }^{2}$ dan Yuridika Prawira Rachmadi ${ }^{3}$}

1Universitas Muhammadiyah Malang, E-mail: yaris@umm.ac.id

${ }^{2}$ Universitas Brawijaya Malang, E-mail: achfaisolt@yahoo.com

3Universitas Muhammadiyah Malang, E-mail: yuridikadika@gmail.com

Info Artikel
Masuk : 17 Juli 2020
Diterima : 29 Desember 2020
Terbit : 31 Desember 2020
Keywords :
Ideological Delict; Communist:
Renewal of Indonesian
Criminal Law
10.24843/KP.2020.v42.i03.p05
Yorresponding Author:
Yaris Adhial Fajrin, E-mail:
yaris@umm.ac.id
Delik Ideologi; Komunisme;
Indonesia

\begin{abstract}
The Indonesian criminal law system recognizes that there are various kinds of criminal acts, among others those related to the prohibition against the dissemination of certain ideologies, or what can be referred to as ideological delict. This ideological delict is related to the spread of Communism ideology, MarxistLeninism which cannot be separated from the dark history of the Indonesian State. This paper is intended to analyze the formulation of the ideological delict in Indonesian positive law and to examine the ideological delict from the aspect of the renewal of Indonesian criminal law. The research method used is normative juridical research, because the problems raised depart from the prevailing criminal law norm system. The results indicated that the formulation of ideological crimes in the Indonesian Criminal Code and the Draft of Indonesian Criminal Code have similar formulations. The formulation of ideological delict has juridical problems, especially in terms of the elements of the act, type, and object of the criminal acts. Therefore, it is necessary to reformulate the ideological delict in the Draft of Indonesian Criminal Code, by taking into account the political direction of Indonesian criminal law which is based on the values of Pancasila.
\end{abstract}

\section{Abstrak}

Sistem hukum pidana Indonesia mengenal adanya berbagai macam tindak pidana, di antaranya tindak pidana yang berkaitan dengan larangan terhadap penyebarluasan ideologi-ideologi tertentu, atau yang bisa disebut dengan istilah delik ideologi. Delik ideologi ini berkaitan dengan penyebaran ideologi Komunisme, Marxis-Leninisme yang tidak bisa dipisahkan dari sejarah kelam Negara Indonesia. Tulisan ini ditujukan untuk menganalisis formulasi rumusan delik ideologi dalam hukum positif Indonesia serta untuk mengkaji delik ideologi tersebut dari aspek pembaruan hukum pidana Indonesia. Metode penelitian yang digunakan adalah penelitian yuridis normatif, karena permasalahan yang diangkat beranjak dari sistem norma hukum pidana yang berlaku. Hasil penelitian menunjukkan bahwa formulasi rumusan tindak pidana ideologi di dalam Kitab Undang-Undang Hukum Pidana (KUHP) maupun Rancangan KUHP (RKUHP) memiliki rumusan yang tidak jauh berbeda. Rumusan delik ideologi tersebut memiliki problematika yuridis 
khususnya dari aspek unsur perbuatan, jenis, dan objek tindak pidana. Maka dari itu perlu dilakukan reformulasi delik ideologi di dalam RKUHP, dengan memperhatikan arah politik hukum pidana Indonesia yang berbasiskan pada nilai-nilai Pancasila.

\section{Pendahuluan}

Kehidupan manusia modern telah membawa pengaruh terhadap kebutuhan manusia akan sebuah organisasi sebagai wadah menjalankan kehidupan. Organisasi dalam catatan sejarah merujuk kepada sebuah bentuk organisasi bernama negara. Aristoteles menggambarkan negara sebagai suatu kekuasaan masyarakat yang bertuj uan untuk menacapai kebaikan tertinggi bagi manusia. ${ }^{1}$ Negara menurut Ibnu Khaldun merupakan masyarakat yang memiliki wazi' (kekuasaan) dan mulk (kewibawaan), ${ }^{2}$ sehingga eksistensi negara akan berkaitan dengan kekuasaan yang melahirkan kewenangan. Eksistensi sebuah negara dengan kewenangan yang dimilikinya melahirkan fungsi dari sebuah negara, sebagaimana pendapat Montesquieu (yang menyempurnakan pemikiran Jhon Locke) mengenai tiga fungsi negara yaitu, fungsi legislatif, fungsi eksekutif, dan fungsi yudikatif (yang kemudian populer dengan istilah trias politika). Negara merupakan organisasi tertinggi pelaksana kekuasaan terhadap suatu daerah tertentu maupun terhadap suatu kumpulan manusia maupun masyarakat tertentu. ${ }^{3}$

Pendapat para pemikir di atas menggambarkan pentingnya fungsi dan kedudukan negara sehingga eksistensinya harus dilindungi melalui sarana hukum, khususnya adalah hukum pidana. Tepatlah jika kepentingan hukum negara menjadi salah satu objek yang perlu untuk dilindungi oleh hukum pidana, ${ }^{4}$ sebab setiap gangguan terhadapnya berdampak pada terganggunya fungsi negara, diantaranya menurut Rousseau, adalah fungsi menjalankan pemerintahan. ${ }^{5}$ Satochid Kartanegara juga mengatakan jika hukum pidana melindungi tiga aspek kepentingan, yaitu individu (individuale belangen), sosial/masyarakat (sociale of maatschappelijke belangen) dan kepentingan negara (staatsbelangen). ${ }^{6}$ Terlihat jelas mengenai alasan kenapa diperlukan suatu upaya perlindungan negara dari segala ancaman, yaitu sebagai sarana antisipatif/preventif terjadinya gangguan-gangguan, sekaligus sarana penegakan hukum terhadap pihak-pihak yang terbukti melakukan gangguan terhadap negara dan pemerintahan.

1 Usman. (2015). Negara dan Fungsinya (Telaah atas Pemikiran Politik). Al-Daulah, 4(1), 130-139. https://doi.org/10.24252/ad.v4i1.1506. p. 132

2 Ibid.

${ }^{3}$ Marbun, R. (2017). Diskursus Perumusan Ideologi Sebagai Perbuatan Pidana dalam Rancangan Kitab Undang-Undang Hukum Pidana 2015. Padjajaran Jurnal Ilmu Hukum, 4(3), 532-550. https://doi.org/10.22304/pjih.v4n3.a6. p. 534.

${ }^{4}$ Chazawi, A., \& Ferdian, A. (2018). Kejahatan Terhadap Negara Kesatuan Republik Indonesia. Jakarta: Sinar Grafika. p. 5.

${ }^{5}$ Usman, Op.cit. p. 135.

6 Dalam: Suhariyono, A.R. (2009). Penentuan Sanksi Pidana Dalam Suatu Undang-Undang. Legislasi Indonesia, 6(4), 615-666. p. 5 
Indonesia telah memilih bentuk negara yaitu negara kesatuan. Amanat perlindungan terhadap bentuk negara Indonesia sebagai negara kesatuan termaktub dalam Pembukaan Undang-Undang Dasar (UUD) 1945 alinea ke-4, yaitu "melindungi segenap bangsa Indonesia dan seluruh tumpah darah Indonesia". Pembukaan UUD 1945 tersebut dapat dimaknai mengenai pentingnya upaya perlindungan terhadap negara kesatuan Republik Indonesia (NKRI), karena hal tersebut berimplikasi pula terhadap kehidupan rakyat Indonesia sebagai bagian dari tumpah darah Indonesia. Memperhatikan dasar alasan tersebut maka muncul lah konsep keamanan negara yang dituangkan dalam suatu peraturan perundang-undangan, diantaranya adalah Kitab Undang-undang Hukum Pidana (KUHP) Indonesia saat ini. ${ }^{7}$ Diantara sekian banyak jenis delik mengenai keamanan negara, ada salah satu delik yang berkaitan langsung dengan topik pembahasan dalam tulisan ini, yaitu delik ideologi. ${ }^{8}$ Terminologi "delik ideologi" sebagaimana yang dimaksud di dalam tulisan ini merupakan delik-delik terkait pelarangan beberapa ideologi (Komunisme, Marxis-leninisme, dan Atheisme, serta mengenai Partai Komunis Indonesia/PKI) yang dipandang bertentangan dengan ideologi Bangsa Indonesia yaitu ideologi Pancasila.

Ideologi memiliki peran penting terhadap eksistensi suatu negara yang akan memberikan pengaruh di tiap sendi dan sektor kehidupan bangsa, tidak terkecuali Indonesia dengan ideologi Pancasila-nya. Jika dikaitkan dengan sistem hukum Indonesia maka Pancasila diposisikan sebagai basic norm, yang berarti bahwa Pancasila merupakan pedoman dalam menjalankan hukum Indonesia. ${ }^{9}$ Memperhatikan hal tersebut maka upaya perlindungan dari segala perbuatan yang ingin mengubah ideologi bangsa, mutlak untuk dilakukan. Mengingat ideologi bangsa tersebut sudah melalui perjalanan pemikiran panjang untuk disesuaikan dengan kondisi konfigurasi sosial suatu negara, tidak terkecuali Pancasila yang dikristalisasi dari nilai-nilai, adat istiadat dan kebudayaan masyarakat bangsa Indonesia, sehingga menyatu dengan kehidupan bangsa. ${ }^{10}$ Secara yuridis, delik ideologi diatur dalam Undang-undang Nomor 22 Tahun 1997 tentang Perubahan Kitab Undang-Undang Hukum Pidana Yang Berkaitan Dengan Kejahatan Terhadap Keamanan Negara (selanjutnya disebut dengan Pasal 107a sampai dengan Pasal 107f KUHP). Keberadaan ketentuan tersebut sebagai akibat sejarah kelam bangsa Indonesia terhadap PKI, yang oleh Andi Hamzah disebut sebagai trauma masa lalu bangsa Indonesia. ${ }^{11}$ Keberadaan delik ideologi ini bukanlah tanpa permasalahan, sebab dalam prakteknya sering dipakai untuk memidana pihakpihak yang dinilai cerminan atau pro ideologi-ideologi terlarang tersebut, seperti

Agustian, R. A. (2011). Tindak Pidana Terhadap Keamanan Negara Dalam Perspektif Delik Politik di Indonesia. Masalah-Masalah Hukum, 40(3), 344-348. https://doi.org/10.14710/mmh.40.3.2011.344-348. p. 344.

8 Terminologi "delik ideologi" sebagaimana yang penulis pakai dalam tulisan ini, juga dipakai oleh Andi Hamzah. Lihat: Hamzah, A. (2000). Tindak Pidana Terhadap Proses Kehidupan Ketatanegaraan Dalam Rancangan KUHP Baru. Aliansi Nasional Reformasi KUHP, 1-6. p. 4-5.

9 Triwijaya, A. F., Fajrin, Y. A., \& Wibowo, A. P. (2020). Quo Vadis: Pancasila Sebagai Jiwa Hukum Indonesia. Jurnal Pendidikan PKN (Pancasila Dan Kewarganegaraan), 1(2), 115-129. https://doi.org/10.26418/jppkn.v1i2.41083. p. 115

10 Mahfud MD, M. (2018). Membangun Jati Diri Bangsa: Globalisasi sebagai Tantangan dan Pancasila sebagai Imperatif Solusi. Sabda 13(2), 145-153. https://doi.org/10.14710/ sabda.13.2, 145-153. p 147-148

11 Andi Hamzah. (2000). Op.cit. p. 3. 
perkara Heri Budiawan alias Budi Pego yang dinyatakan bersalah karena secara melawan hukum melakukan perbuatan penyebaran ajaran komunisme. ${ }^{12}$

Terdapat beberapa tulisan atau karya ilmiah yang menjadi acuan tulisan ini. Pertama, tesis karya Ady Irawan di tahun 2012 berjudul "Kebijakan Formulatif Hukum Pidana Tentang Kriminalisasi Ideologi Komunisme/Marxisme-Leninisme Sebagai Kejahatan Terhadap Keamanan Negara Dalam Undang-Undang Nomor 27 Tahun 1999 Tentang Perubahan KUHP Yang Berkaitan Dengan Kejahatan Terhadap Keamanan Negara". Tesis tersebut hanya berfokus pada arah kebijakan kriminalisasi dan ancaman pidana delik ideologi di dalam Undang-undang No. 27 Tahun 1999, belum mengkaji delik ideologi dari perspektif pembaruan hukum pidana Indonesia. ${ }^{13}$ Kedua, artikel ilmiah karya M. Subhan berjudul "Perlindungan Hukum Bagi Penganut Ideologi Komunisme/Marxisme-Leninisme di Indonesia" tahun 2020. ${ }^{14}$ Artikel karya M. Subhan tersebut berfokus pada upaya dan bentuk perlindungan hukum bagi penganut Ideologi Komunisme/Marxisme-Leninisme, yang itu belum menyentuh aspek pembaruan hukum pidana Indonesia. Ketiga, artikel ilmiah karya Andreas Purba dan Firman Wijaya, tahun 2019, yang berjudul "Analisis Putusan Nomor 559/Pid.B/2017/Pn.Byw. Pengadilan Negeri Banyuwangi Tentang Penyebaran Ajaran Komunisme/MarxismeLeninisme Secara Melawan Hukum Berdasarkan Pasal 107a KUHP" ${ }^{15}$ Meskipun analisa dalam artikel tersebut berfokus pada satu perkara terkait delik ideologi tetapi hasil analisanya memberikan gambaran bagi penulis mengenai adanya problematika delik ideologi khususnya dalam penerapannya.

Mendasarkan pada latar belakang tersebut penulis berpandangan bahwa perlu ada upaya untuk menelaah kembali formulasi delik ideologi dalam hukum pidana positif Indonesia, mengingat Pancasila sebagai ruh dan jiwa bangsa Indonesia justru kaya akan nilai-nilai Ketuhanan, kemanusiaan, keadilan, dan persatuan. Terlebih di dalam draft Rancangan KUHP Nasional 2019 masih mengenal adanya delik ideologi, sehingga membuka peluang penggunaan delik tersebut di masa mendatang. Maka dari itu gagasan penulis ini diharapkan dapat memperkaya khasanah keilmuan khususnya dalam rangka pembaruan hukum pidana nasional sekaligus sebagai upaya melindungi Negara Kesatuan Republik Indonesia (NKRI) dari segala bentuk ancamannya. Memperhatikan hal tersebut maka tulisan ini mengangkat dua buah permasalahan, yaitu: pertama, bagaimana pengaturan delik ideologi dalam hukum pidana positif Indonesia? dan kedua, bagaimana reformulasi delik ideologi dari perspektif pembaruan hukum pidana indonesia?

12 Purba, A., \& Wijaya, F. (2019). Analisis Putusan Nomor 559/Pid.B/2017/Pn.Byw. Pengadilan Negeri Banyuwangi Tentang Penyebaran Ajaran Komunisme/Marxisme-Leninisme Secara Melawan Hukum Berdasarkan Pasal 107a KUHP. Jurnal Hukum Adigama, 2(3), 1-22. https:// doi.org/10.24912/adigama.v2i2.6907. p. 3.

13 Irawan, A. (2012). Kebijakan Formulatif Hukum Pidana Tentang Kriminalisasi Ideologi Komunisme / Marxisme - Leninisme Sebagai Kejahatan Terhadap Keamanan Negara Dalam Undang-Undang Nomor 27 Tahun 1999 Tentang Perubahan KUHP Yang Berkaitan Dengan Kejahatan Terhadap Keamanan Negara. Yogyakarta: Universitas Islam Indonesia. p. 15.

14 Subhan, M. (2019). Perlindungan Hukum Bagi Penganut Ideologi Komunisme/MarxismeLeninisme Di Indonesia. Mimbar Keadilan, 12(2), 138-154. https://doi.org/10.30996/mk.v12i2.2385. p. 142.

15 Purba, A., \& Wijaya, F. (2019). Op.cit., p. 6. 


\section{Metode Penelitian}

Tulisan ini menggunakan jenis penelitian yuridis-normatif yakni pokok permasalahan terletak pada rumusan norma dalam undang-undang, yang menitikberatkan pada rumusan delik ideologi dalam hukum pidana positif Indonesia. Penulis menggunakan pendekatan penelitian perundang-undangan dan pendekatan historis. Bahan hukum yang penulis gunakan berasal dari peraturan perundang-undangan dan literatur yang berkaitan dengan tulisan ini. Penulis menggunakan Teknik analisa interpretasi gramatikal dan sistematis untuk menganalisa bahan hukum.

\section{Hasil dan Pembahasan}

\subsection{Delik Ideologi Dalam Bingkai Hukum Pidana Positif Indonesia 3.1.1. Delik Ideologi Dalam Berbagai Undang-Undang di Indonesia}

Bangsa Indonesia telah sepakat menjadikan Pancasila sebagai dasar sekaligus ideologinya, sebagaimana pidato Ir. Soekarno pada sidang BPUPKI pada tanggal 1 Juni 1945. ${ }^{16}$ Jimly Asshiddiqie menyebut Pancasila sebagai ideologi terbuka, ${ }^{17}$ karena sifatnya yang inklusif, tidak totaliter dan tidak dapat dipakai melegitimasi kekuasaan sekelompok orang..$^{18}$ Hal tersebut berkebalikan dengan komunisme dan ideologi kiri lainnya yang justru berbentuk ideologi tertutup, ${ }^{19}$ sehingga cenderung menggunakan cara-cara yang dipaksakan. Maka tidak mengherankan jika di beberapa sejarah negaranegara di dunia sering terjadi perbenturan sosial/masyarakat dan penguasa yang dilatarbelakangi oleh persoalan ideologi (khususnya ideologi komunis). Seperti peristiwa revolusi Bolsyewik di Rusia (saat itu bernama Uni Soviet) sekitar tahun 1917 yang turut menggoncang Eropa. Salah satunya Belanda, yang mengeluarkan undangundang anti-revolusi melalui Staatsblad no. 619 tahun 1920 untuk mengatur aanslag (delik makar) sebagai langkah deterrence meletusnya revolusi yang sama di negaranya. ${ }^{20}$ Delik aanslag tersebut pun diadopsi ke dalam Wetboek van Strafrecht (WvS) yang diterapkan Belanda di Indonesia sebagai negara jajahannya, dan digunakan untuk mengatasi pemberontakan PKI tahun 1926 di Semarang. ${ }^{21}$ Hingga saat ini pun aanslag masih diadopsi oleh KUHP Indonesia, yaitu pada Pasal 87 jo. Pasal 104, Pasal 106, Pasal 107.

16 Presiden Soekarno menyebut Pancasila sebagai Philosofische grondslag, sebab Pancasila merupakan fundamen, filsafat, pikiran berdirinya negara Indonesia. Lihat: Asshiddiqie, J. (2008). Ideologi, Pancasila, dan konstitusi. Mahkamah Konstitusi Republik Indonesia, (1), 1-23. p. 13

17 Ibid., p. 7.

18 Ibid., pl. 3.

19 Ideologi tertutup merupakan pandangan atau ajaran yang menentukan tujuan maupun norma sosial-politik yang diyakini sebagai kebenaran mutlak yang harus diterima dan dipatuhi. Ideologi ini bersifat apriori dan dogmatis yang tidak mentoleransi perubahan atau modifikasi dari pandangan atau nilai-nilai lain. Lihat: Suseno, F. M. (1992). Filsafat Sebagai Ilmu Kritis. Yogyakarta: Kanisius. p. 232-233.

20 Kegoncangan hebat di Eropa akibat meletusnya revolusi Bolsyewik atau komunis di Rusia tahun 1917 yang dipimpin oleh Lenin, di mana Raja atau Tsar Nicolas II beserta seluruh keluarganya dibantai oleh golongan komunis Bolsyewik, sehingga memunculkan kekhawatiran akan pecahnya revolusi yang serupa di seluruh Eropa termasuk Belanda. Lihat: Andi Hamzah (2000) Op.cit. p. 2-4

21 Ibid., p. 5. 
Komunisme yang termanifestasikan dalam eksistensi Partai Komunis Indonesia (PKI) di masa lalu, telah menjadi bagian sejarah kelam bangsa Indonesia. Puncaknya adalah ketika PKI dipandang sebagai pihak yang paling bertanggung jawab terhadap Gerakan 30 September 1965 (G.30.S/PKI) yang akhirnya menimbulkan gejolak sosial berupa perlawanan, penangkapan, hingga pembunuhan terhadap anggota-anggota PKI di seluruh daerah di Indonesia. Peristiwa kelam itu lah yang mendasari diterbitkannya TAP MPRS No. XXV/MPRS/1966. ${ }^{22}$ Hingga sampai periode awal reformasi, yaitu pada masa pemerintahan Presiden B.J. Habibie, menetapkan Undang-undang Nomor 27 Tahun 1999, berisi enam pasal baru yang disisipkan diantara Pasal 107 dan Pasal 108 Kitab Undang-undang Hukum Pidana (selanjutnya disebut dengan Pasal 107a - 107f KUHP). Keenam pasal baru KUHP menurut Undang-undang No. 27 Tahun 1999 tersebut isinya adalah sebagai berikut:

\section{Tabel 1. Delik Ideologi di Dalam KUHP}

\begin{tabular}{|c|c|}
\hline Pasal & Isi \\
\hline $107 a$ & $\begin{array}{l}\text { "Barangsiapa yang secara melawan hukum di muka umum dengan lisan, tulisan, } \\
\text { dan atau melalui media apapun, menyebarkan atau mengembangkan ajaran } \\
\text { Komunisme/Marxisme-Leninisme dalam segala bentuk dan perwujudan." } \\
\text { Penjelasan Pasal: } \\
\text { "Yang dimaksud dengan Komunisme/Marxisme-Leninisme adalah paham atau } \\
\text { ajaran Karl Marx yang terkait pada dasar-dasar dan taktik perjuangan yang } \\
\text { diajarkan oleh Lenin, Stalin, Mao Tse Tung dan lain-lain, mengandung benih-benih } \\
\text { dan unsur-unsur yang bertentangan dengan falsafah Pancasila." } \\
\text { (Yang selanjutnya dalam tulisan ini disebut dengan Ideologi kiri) }\end{array}$ \\
\hline $107 \mathrm{~b}$ & $\begin{array}{l}\text { "Barang siapa yang secara melawan hukum di muka umum dengan lisan, tulisan } \\
\text { dari atau melalui media apapun, menyatakan keinginan untuk meniadakan atau } \\
\text { mengganti Pancasila sebagai dasar negara yang berakibat timbulnya kerusuhan } \\
\text { dalam masyarakat, atau menimbulkan korban jiwa atau kerugian harta bendal" }\end{array}$ \\
\hline $107 \mathrm{c}$ & $\begin{array}{l}\text { "Barangsiapa yang secara melawan hukum di muka umum dengan lisan, tulisan dan } \\
\text { atau melalui media apapun, menyebarkan atau mengembangkan ajaran Komunisme/ } \\
\text { Marxisme-Leninisme yang berakibat timbulnya kerusuhan dalam masyarakat, } \\
\text { atau menimbulkan korban jiwa atau kerugian harta benda" }\end{array}$ \\
\hline $107 d$ & $\begin{array}{l}\text { "Barangsiapa yang secara melawan hukum di muka umum dengan lisan, tulisan dan } \\
\text { atau melalui media apapun, menyebarkan atau mengembangkan ajaran Komunismel } \\
\text { Marxisinc-Leninisme dengan maksud mengubah atau mengganti Pancasila sebagai } \\
\text { dasar Negara" }\end{array}$ \\
\hline $107 \mathrm{e}$ & $\begin{array}{l}\text { a. "barang siapa yang mendirikan organisasi yang diketahui atau patut diduga } \\
\text { menganut ajaran Komunisme/ Marxisme-Leninisme atas dalam segala bentuk } \\
\text { dan perwujudannya;" }\end{array}$ \\
\hline
\end{tabular}

22 TAP MPRS No. XXV/MPRS/1966 tentang Pembubaran Partai Komunis Indonesia, Pernyataan sebagai Organisasi Terlarang di seluruh Wilayah Negara Republik Indonesia Bagi Partai Komunis Indonesia dan Larangan Setiap Kegiatan Untuk Menyebarkan atau Mengembangkan Faham atau Ajaran Komunisme/Marxisme/Leninisme. 


\begin{tabular}{|l|l|}
\hline "barang siapa yang mengadakan hubungan dengan atau memberikan bantuan \\
kepada organisasi, baik didalam maupun di luar tiegeri, yang diketahuinya \\
berasaskan ajaran Komunisme/ Marxisme-Leninisme atau dalam segala, bentuk \\
dan perwujudannya dengan maksud mengubah dasar negara atau \\
menggulingkan Pemerintah yang sah."
\end{tabular}

Dari enam pasal yang disisipkan, ${ }^{23}$ lima diantaranya (Pasal 107a - Pasal 107e KUHP) penulis sebut sebagai delik ideologi, karena menjadikan ideologi dan dasar negara Indonesia (yaitu Pancasila) sebagai objek yang dilindungi oleh hukum pidana. ${ }^{24}$ Mengenai macam-macam perbuatan yang dilarang, penulis membaginya menjadi dua ketegori:

1) Perbuatan yang berlatarbelakang ideologi kiri, sebagaimana tertuang di Pasal 107a, Pasal 107c, Pasal 107d, dan Pasal 107e, meliputi perbuatan:

a. Menyebarkan atau mengembangkan ajaran kiri, ${ }^{25}$ yang terbagi dalam tiga bentuk:

i. Perbuatan tersebut memiliki dampak sosial dan akibat korban jiwa/harta (Pasal 107c);

ii. Perbuatan tersebut dimaksudkan ${ }^{26}$ untuk mengubah/mengganti Pancasila (Pasal 107d); dan

iii. Perbuatan tersebut tanpa diikuti unsur dampak/akibat maupun maksud (107a).

b. Perbuatan mendirikan organisasi yang menganut ideologi kiri (Pasal 107e huruf a); dan

c. Perbuatan keterlibatan (berhubungan dan membantu) dengan organisasi berideologi kiri, dalam maupun luar negeri (Pasal 107e huruf b).

2) Perbuatan yang berlatarbelakang selain ideologi kiri, yaitu Pasal $107 \mathrm{~b}$ berupa perbuatan menyatakan keinginan meniadakan atau mengganti Pancasila yang berakibat timbulnya kerusuhan atau korban jiwa maupun kerugian dalam masyarakat.

Selain menerangkan mengenai unsur perbuatan, unsur akibat, unsur melawan hukum ${ }^{27}$, dan unsur kesengajaan (sebagai maksud), di dalam rumusan delik ideologi KUHP

23 Model perubahan KUHP sebagaimana yang diatur di dalam Undang-undang Nomor 27 Tahun 1999 merupakan bentuk perubahan model evolusioner, karena undang-undang tersebut berisi perubahan isi ketentuan di dalam KUHP sehingga secara formil ia merupakan bagian dari satu kesatuan dengan KUHP. Lihat: Irawan, A. (2012), Op.cit. p. 169.

24 Sedangkan Pasal 107f disebut sebagai delik sabotase, yang objeknya adalah keamanan dan pertahanan negara, bukan spesifik terhadap ideologi atau dasar negara yaitu Pancasila.

25 Perbuatan "menyebarkan" diartikan "menyampaikan kepada orang banyak", sedangkan perbuatan "mengembangkan" diartikan sebagai "menjadikan sesuatu bertambah banyak, bertambah sempurna/lengkap, dan berkembang dari keadaan semula". Lihat: Chazawi, A., \& Ferdian, A. (2018). Op.cit. p. 40.

26 Unsur "maksud" dalam hal ini merupakan bentuk dari unsur kesengajaan/dolus, yaitu kesengajaan sebagai maksud. Adami Chazawi menyebutnya sebagai kesengajaan dalam arti sempit, yang itu hanya ditujukan untuk tujuan mengubah/mengganti Pancasila sebagai dasar negara. Lihat: Ibid.

27 Jika dicermati, mengenai unsur melawan hukum (dan tidak berbeda jauh pula dengan rumusan unsur kesengajaan) dalam rumusan delik ideologi tersebut ada beberapa yang 
tersebut juga memuat mengenai unsur "cara yang dilakukan" yang terdapat di Pasal 107a sampai dengan Pasal Pasal 107d, yaitu berupa unsur "dengan lisan, tulisan, dan atau melalui media apapun" yang itu selalu mengikuti unsur "di muka umum" 28 .

Selain KUHP, terdapat pula ketentuan pidana mengenai delik ideologi di luar KUHP. Sebatas penelusuran penulis, delik-delik ideologi di luar KUHP meliputi: Undangundang No. 2 Tahun 2008 tentang Partai Politik, ${ }^{29}$ Undang-undang No. 5 Tahun 2018 tentang Perubahan Atas Undang-Undang Nomor 15 Tahun 2003 tentang Penetapan Peraturan Pemerintah Pengganti Undang-Undang Nomor 1 Tahun 2002 Tentang Pemberantasan Tindak Pidana Terorisme Menjadi Undang-Undang, ${ }^{30}$ Undang-undang No. 16 Tahun 2017 tentang Penetapan Peraturan Pemerintah Pengganti UndangUndang Nomor 2 Tahun 2017 Tentang Perubahan Atas Undang-Undang Nomor 17 Tahun 2013 Tentang Organisasi Kemasyarakatan Menjadi Undang-Undang, jo. Undangundang No. 17 Tahun 2013 tentang Organisasi Kemasyarakatan. ${ }^{31}$

Penjabaran ketentuan sebagaimana tersebut di atas memberikan gambaran bahwa ideologi kiri masih dipandang sebagai suatu ancaman terhadap kelangsungan ideologi negara Indonesia yaitu Pancasila. Tetapi yang perlu diingat adalah bahwa ancaman terhadap eksistensi Pancasila serta ancaman terhadap pertahanan dan keamanan NKRI, untuk saat ini dan untuk masa yang akan datang, tidak semata pada segala perbuatan yang berlatar belakang ideologi kiri melainkan juga ideologi-ideologi lainnya. Sejarah mencatat, ada berbagai peristiwa pemberontakan dan perlawanan yang berlandaskan pada motif ideologi di luar ideologi kiri, seperti gerakan PRRI-Permesta ${ }^{32}$ atau gerakan

mencantumkannya secara tersurat (Pasal 107a s/d Pasal 107d) dan ada pula yang tidak dicantumkan (Pasal 107e). Artinya adalah bahwa kedua unsur tersebut (Unsur sengaja dan unsur melawan hukum) yang terselubung (tersirat, pen.) secara serta merta telah melekat pada unsur perbuatan, sehingga ketika unsur perbuatan terbuktikan maka secara serta merta unsur sengaja dan melawan hukum pun telah terpenuhi/terbuktikan. Lihat: Ibid., p. 41

28 Unsur "di muka umum" diartikan sebagai suatu tempat yang sebenar-benarnya berisi banyak orang. Sehingga kualifikasi tempat dalam hal ini tidak semata pada tempat yang biasanya dikunjungi/ditempati oleh banyak orang, tetapi harus ada wujud jumlah banyaknya orang. Sebab melihat rumusan dan tujuan dari delik ideologi Pasal 107a - Pasal 107d maka "di muka umum" ini ditujukan agar orang banyak mengetahui ajaran kiri tersebut. Lihat: Ibid., p. 42.

29 Pasal 40 ayat (5). Melarang partai politik berhaluan pada ideologi kiri. Terdapat dua bentuk sanksi di pasal tersebut: pertama, sanksi administrasi berupa pembubaran partai (Pasal 48 ayat (7)) dan kedua, sanksi pidana terhadap pengurusnya (Pasal 50).

30 Pasal 1 angka 2 menerangkan mengenai motif ideologi dalam tindak pidana terorisme.

31 Perubahan Pasal 59 ayat (4) huruf c melarang ormas berhaluan ideologi yang bertentangan Pancasila. Undang-undang No. 16 Tahun 2017 juga mengenal dua jenis sanksi (administrasi dan pidana). Hal yang cukup menarik UU Ormas mengenal ketentuan sanksi pidana tersendiri yang tidak mengacu kepada KUHP sebagaimana yang terdapat di UU Parpol. Selain itu, UU Ormas memiliki ketentuan batas maksimum dan minimum sanksi pidana.

32 Setelah menelaah artikel yang ditulis oleh Faishal Hilmy Maulida, Penulis berpendapat bahwa gerakan PRRI-Permesta secara garis besar merupakan gerakan yang didasarkan pada dua visi, yaitu visi kedaerahan dan visi nasionalisme Keindonesiaan, sehingga dapat penulis garis bawahi adanya kecenderungan ideologi nasionalisme sempit yang mendasari gerakan mereka. Lihat: Maulida, F. H. (2018). Hitam Putih PRRI-Permesta: Konvergensi Dua Kepentingan Berbeda 1956-1961. Paradigma: Jurnal Kajian Budaya, 8(2), 174. https://doi.org/10.17510/paradigma.v8i2.180. p. 174-185. 
DI-TII. ${ }^{33}$ Dapat pula berkaca dari berbagai peristiwa terorisme yang berafiliasi dengan organisasi luar negeri seperti Jamaah Islamiyah dan ISIS, yang notabene merupakan organisasi yang menggunakan stigma agama sebagai dasar gerakan dan propagandanya. Memperhatikan hal tersebut maka ada benarnya jika UU Ormas Pasal 59 ayat (4) pada bagian penjelasannya menggunakan frasa “... paham lain yang bertujuan mengganti/mengubah pancasila dan Undang-Undang Dasar Negara Republik Indonesia Tahun 1945", yang itu artinya pemerintah menyadari akan ancaman lain selain yang berlatarbelakang ideologi kiri.

\subsubsection{Telaah Yuridis Terhadap Delik Ideologi Dalam KUHP Indonesia}

Bagian ini penulis akan menelaah ketentuan delik ideologi di KUHP, yaitu Pasal 107a Pasal 107e sebagaimana yang telah diuraikan di atas. Adapun alasan penulis menjadikan ketentuan di dalam KUHP sebagai objek kajian adalah: pertama, karena ketentuan tersebut bersifat lebih umum daripada ketentuan lain di luar KUHP sehingga rentan untuk dipakai kepada masyarakat secara umum; kedua, karena tidak sedikit perkara pidana yang menjadikan pasal-pasal tersebut sebagai dasar putusan perkara; dan ketiga, saat ini Indonesia sedang dalam masa perumusan Rancangan KUHP baru (selanjutnya disebut RKUHP). Guna mengakomodir alasan pertama dan kedua di atas, penulis paparkan diagram berikut ini mengenai beberapa putusan pidana terkait delik ideologi:

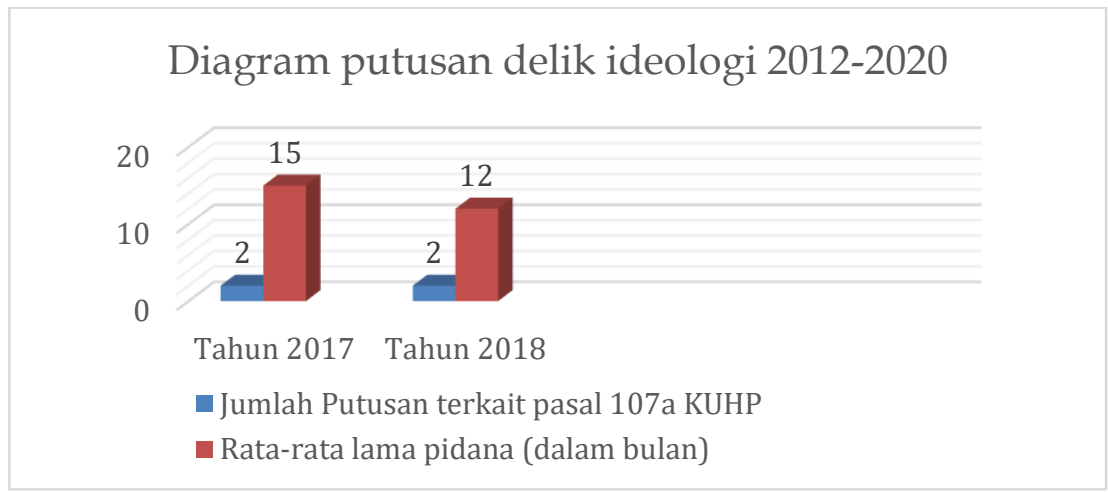

Sumber: Diolah dari website direktori putusan Mahkamah Agung RI. ${ }^{34}$

33 Salah satu tokoh pemberontakan DI-TII adalah Kahar Muzakar (selain Kartosuwiryo). Pada awalnya gerakannya, ia menggunakan ideologi Pancasila. Tapi ketika ia dan kelompoknya bergabung dengan DI-TII, arah gerakannya berubah menjadi gerakan yang berideologikan Islam. Lihat: Azizah, N. (2019). Islamisme: Ideologi Gerakan Kahar Mudzakkar di Sulawesi Selatan 1952-1965. Jurnal Penelitian Keislaman, 15(2), 95-104. https://doi.org/10.20414/jpk.v15i2.1585. p. 96.

34 Mahkamah Agung Republik Indonesia. (n.d.). Direktori Putusan: Publikasi Dokumen Elektronik Putusan Seluruh Pengadilan Di Indonesia. Retrieved July 3, 2020, from Direktori Putusan Mahkamah Agung Republik Indonesia website: https:// putusan3.mahkamahagung.go.id// diakses tanggal 3 Juli 2020 
Diagram tersebut menunjukkan bahwa delik ideologi masih eksis digunakan, khususnya Pasal 107a KUHP, sebagaimana terdapat di dalam putusan: Nomor 288/Pid.B/2017/PN Blb, Nomor 140/Pid.B/2017/PN KNG, Nomor 293/Pid.B/2018/PNKwg dan Nomor 559/PID.B/2017/PN.BYW. Apabila lebih dicermati lagi dari keempat putusan tersebut pertimbangan hakim pada prinsipnya mengikuti undang-undang yang berlaku atau mengikuti status quo. Penulis mengambil contoh putusan perkara Nomor 559/PID.B/2017/PN.BYW dengan terdakwa Budi Pego, di mana tindakan pencantuman logo palu dan arit dilakukan oleh usulan seseorang sehingga tidak dimaksudkan untuk menyebarkan atau mengembangkan ajaran komunisme. ${ }^{35}$ Diagram tersebut pun semakin diperkuat dengan apa yang ditulis oleh M. Subhan dalam artikelnya, yang menyebutkan bahwa terjadi beberapa tindakan over reactive yang dilakukan oleh aparat terhadap hal-hal yang berbau komunis. ${ }^{36}$

Merunut sejarah pembentukannya, pada awalnya Pasal 107a tersebut memiliki rumusan yang berbeda dari apa yang ada saat ini. Bunyi awal pasal tersebut adalah: ${ }^{37}$

"Setiap orang yang secara melawan hukum di muka umum, baik secara lisan maupun tulisan, menyatakan keinginan untuk meniadakan atau mengganti Pancasila sebagai dasar negara yang dapat berakibat timbulnya keonaran atau kerusuhan dalam masyarakat, atau menimbulkan korban jiwa ...."

Rancangan Pasal 107a tersebut pada akhirnya di-drop dan dipecah menjadi dua pasal yaitu Pasal 107c dan 107d. Adami Chazawi menyebutkan bahwa Pasal 107a merupakan bentuk pokok atau lex generalis ${ }^{38}$ dari pasal-pasal delik ideologi lainnya, karena dari segi historis memiliki riwayat perumusan yang demikian tersebut. Penulis sendiri menyebut bahwa ketentuan pasal 107c dan Pasal 107d merupakan turunan dari Pasal 107a. Secara rinci, dapat penulis gambarkan dalam bagan berikut:

Bagan 1. Kaitan Pasal 107a, 107c, dan 107d KUHP

35 Analisis lengkap mengenai perkara tersebut, dapat dibaca dalam artikel ilmiah karangan Andreas Purba. Lihat: Purba, A., \& Wijaya, F. (2019). Op.cit. p. 1-22

36 Tindakan tersebut seperti: penyitaan kaos bergambar sampul album band metal asal Jerman "Kreator" karena ada logo palu dan arit mirip lambang PKI, pembubaran konser musik reggae karena salah satu band bernama "Mesin Sampink" memainkan lagu "genjer-genjer" yang identik dengan PKI, atau razia dan penyitaan sejumlah buku sejarah dan biografi tokohtokoh PKI. Lihat: Subhan, M. (2019). Op.cit. p. 141.

37 Irawan, A. (2012), Op.cit. p. 200.

38 Chazawi, A., \& Ferdian, A. (2018). Op.cit. p. 37 


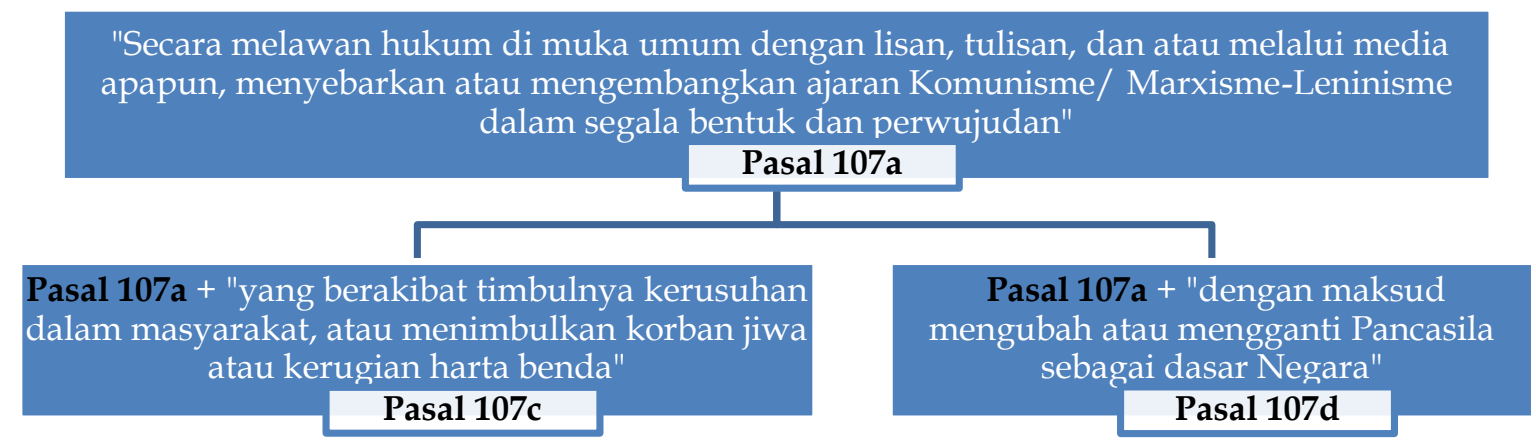

Sifat generalis yang dimiliki oleh Pasal 107a atas delik-delik ideologi lainnya, tergambarkan pula pada bobot sanksi yang diancamkan, di mana terhadap delik-delik ideologi yang lex specialis hukumannya lebih berat dibandingkan dengan Pasal 107a. Sebab untuk yang delik ideologi yang bersifat khusus memiliki unsur pemberat, seperti unsur akibat "timbulnya kerusuhan dalam masyarakat, atau menimbulkan korban jiwa atau kerugian harta benda" di dalam Pasal 107c, atau unsur kesengajaan berupa "dengan maksud mengubah atau mengganti Pancasila sebagai dasar Negara", di dalam Pasal 107d.

Pasal 107a menerangkan larangan yang termuat secara umum, sehingga pasal tersebut merupakan delik formil (formeel delict). Delik formil oleh SR. Sianturi diartikan sebagai "tindakan yang dilarang (beserta hal/keadaan lainnya) dengan tidak mempersoalkan akibat dari tindakan itu", ${ }^{39}$ atau pendapat Moeljatno yang menyebutkan delik formil sebagai "delik yang perumusannya hanya menekankan pada perbuatannya saja tanpa mensyaratkan adanya akibat". ${ }^{40}$ Begitu pula Jan Remmelink yang menjelaskan delik formil sebagai tindak pidana yang didalamnya cukup disebut dengan merujuk pada perbuatan tertentu. ${ }^{41}$ Memperhatikan uraian tersebut maka yang menjadi pokok larangan dalam delik formil ini adalah terletak pada melakukan atau selesainya melakukan perbuatan tertentu tanpa melihat akibat yang ditimbulkan, atau oleh van Hamel disebut dengan istilah voltooid delict. ${ }^{42}$ Memperhatikan rumusan mengenai formeel delict oleh beberapa ahli hukum di atas, maka bentuk delik formil ini tidak hanya untuk Pasal 107a saja tetapi juga Pasal 107d. Maka dari keseluruhan delik ideologi di dalam KUHP hanya dua pasal tersebut yang diidentifikasi sebagai delik formil (sedangkan di luar kedua pasal tersebut masuk kategori delik materiil ${ }^{43}$ ). Perumusan delik formil untuk delik ideologi semakin diperkuat oleh pendapat Mudzakir yang menjelaskan bahwa perumusan delik ideologi yang terdapat di UU No 27 Tahun 1999 lebih menekankan kepada perbuatan yang mendahului (dini) sebagai usaha perlindungan

39 S.R. Sianturi, dalam Irawan, A. (2012). Op.cit., hlm 10.

40 Moeljatno, dalam Wibowo, A. (2013). Kebijakan Kriminalisasi Delik Pencemaran Nama Baik di Indonesia. Pandecta: Research Law Journal, 7(1). https://doi.org/10.15294/pandecta.v7i1.2358. p. 8-9

41 Jan Remmelink, Ibid. p 10.

42 Delik yang telah selesai dilakukan oleh pelaku sebenarnya. Lihat: Lamintang, P. A. F. (2013). Dasar-dasar Hukum Pidana Indonesia. Bandung: Citra Aditya Bakti. p. 213.

43 Delik materiil merupakan delik yang menjadi pokok dari rumusannya adalah terletak pada akibatnya. Ciri delik materiil adalah didalamnya terdapat unsur akibat konstitutif, yang mana unsur tersebut menjadi syarat selesainya suatu tindak pidana. Lihat: Chazawi, A. (2013). Op.cit. p. 103-104. 
awal (preventif) terhadap kepentingan masyarakat dan negara dalam mempertahankan ideologi negara. ${ }^{44}$

Keberadaan delik formil di dalam Undang-undang No. 27 Tahun 1999, tidak bisa dilepaskan dari faktor sejarah pembentukannya. Pemberlakuan undang-undang tersebut beriringan dengan pencabutan Penetapan Presiden Republik Indonesia Nomor 11/PNPS/1963 Tentang Pemberantasan Kegiatan Subversi, ${ }^{45}$ di mana isi dalam undangundang subversi tersebut yang dipandang masih relevan ${ }^{46}$ akan diadopsi kembali di dalam Undang-undang No. 27 Tahun 1999. Hal tersebut menggambarkan bahwa terdapat keterkaitan secara substansial antara kedua undang-undang tersebut, sehingga berimplikasi terhadap penggunaan delik formil di dalam rumusan pasal-pasalnya. Berikut penulis mengutip Pasal 1 ayat (1) angka 1 huruf a dalam Penetapan Presiden Republik Indonesia Nomor 11/PNPS/1963 tersebut, sebagai bahan pembanding:

\begin{abstract}
“Barang-siapa melakukan sesuatu perbuatan dengan maksud atau nyatanyata dengan maksud atau yang diketahuinya atau patut diketahuinya dapat: memutarbalikkan, merongrong atau menyelewengkan ideologi negara Pancasila atau haluan negara."
\end{abstract}

Rumusan tersebut menggambarkan bahwa delik formil telah dianut sebelumnya di dalam penetapan presiden tersebut, sehingga hal itu pun sedikit banyak diadopsi ke dalam delik-delik ideolgi di dalam Undang-undang No. 27 Tahun 1999. Selain keterkaitannya dengan Penetapan Presiden Republik Indonesia Nomor 11/PNPS/1963, keberadaan delik formil di dalam Undang-undang No. 27 Tahun 1999 juga didadasarkan pada masukan dari fraksi $\mathrm{ABRI},{ }^{47}$ yang meliputi: pertama, delik kemanan negara (termasuk delik ideologi, pen.) tidak lagi menjadi pasal-pasal karet yang dapat menimbulkan ketidakpastian hukum; dan kedua, pasal yang memuat ketentuan tentang larangan penyebaran dan pengembangan ajaran ideologi kiri tetap dirumuskan sebagai delik formil.

Perumusan delik formil maupun delik materiil untuk tindak pidana berkaitan ideologi sebenarnya masih relevan untuk digunakan agar undang-undang yang dibuat dapat mengikuti perkembangan zaman, tetapi untuk penggunaan delik formil tersebut haruslah dilakukan secara cermat dan hati-hati, khususnya dalam hal merumuskan

44 Oleh sebab itu, perbuatan yang dilarang adalah perbuatan yang ditujukan untuk menyebarkan ajaran ideologi lain yang bertentangan dengan ideologi negara, meskipun akibat adanya usaha penyebaran ideologi lain dan usaha untuk mengganti ideologi negara tidak sampai berhasil. Sebab perbuatan tersebut dapat membawa akibat sosial yang luas dan mengancam keamanan negara serta merusak sendi-sendi kehidupan bernegara. Mudzakkir, Kontroversi Kehadiran PAPERNAS Sebagai Ideologi "Kiri" (Perspektif Politik Hukum Pidana), dalam Irawan, A. (2012). Op.cit. p. 202.

45 Pencabutan undang-undang subversi tersebut didasarkan pada Undang-undang No. 26 Tahun 1999.

46 Penjelasaan Muladi dalam kedudukannya sebagai Menteri Kehakiman di Era Presiden BJ. Habiebie. Lihat: Irawan, A. (2012). Op.cit. p. 171.

47 Ibid., p. 173 dan 174. 
perbuatan yang dilarang. ${ }^{48}$ Sebagaimana pendapat Herbert L. Packer ${ }^{49}$ bahwa hukum pidana yang berorientasi dan bermuara pada sanksi pidana dapat menjadi penjamin yang utama/terbaik (primer guarantor) dan sekaligus sebagai pengancam yang utama (primer threatener) atau merupakan sarana terbaik dalam menghadapi kejahatan. Prinsip kecermatan dan kehati-hatian tidak hanya terhadap penentuan bentuk delik formil, tetapi harus mencakup pula mengenai kejelasan objek perbuatan dalam delik ideologi ini, yaitu ajaran Komunisme/Marxisme-Leninisme..$^{50}$ Muncul pertanyaan, apakah ideologi/mainset/ide/konsep/cita-cita/keyakinan yang dimiliki oleh masing-masing individu dapat dijadikan sebagai alasan memidana/menghukum seseorang? Terlebih lagi mengenai hal tersebut menjadi bagian dari hak asasi manusia mengenai hak kebebasan pribadi, berpikir dan hati nurani. Hak berkenaan dengan kebebasan berpikir saat ini diakui oleh UUD NRI 1945 dan Undang-undang Nomor 39 tahun 1999 tentang Hak asasi manusia serta didalam ICPPR yang telah diratifikasi oleh Indonesia. Mengingat pula, bahwa dalam merumuskan suatu peraturan perundang-undangan yang baik harus memenuhi berbagai asas, salah satunya adalah asas kejelasan rumusan sebagaimana yang termaktub di Pasal 5 Undang-undang No. 12 Tahun 2011 tentang Pembentukan Peraturan Perundang-Undangan. Kejelasan baik diri sisi penggunaan delik formil maupun dalam hal objek tindak pidana tersebut harus mengingat salah satu asas dalam hukum pidana yaitu "nullum criemen, nulla poena sine lege certa" (tidak ada pidana tanpa aturan undang-undang yang jelas). ${ }^{51}$

Delik ideologi kental akan faktor sejarah, khususnya mengenai sejarah kelam bangsa Indonesia dengan PKI. Tidak ada salahnya jika dalam upaya pembaruan hukum pidana nasional, perlu juga memperhatikan trend internasional mengenai perkembangan kejahatan yang ada dewasa ini, diantaranya adalah mengenai fenomena kejahatan terorganisir atau organized crime. ${ }^{52}$ Keberadaan kejahatan model baru tersebut mengilhami perluasan subjek tindak pidana, dari orang menjadi korporasi. Hal tersebut relevan jika dikaitkan dengan sejarah pergerakan yang terjadi di Indonesia sejak negeri ini merdeka, di mana kesemuanya selalu bersifat kelompok dan terorganisir. Menjadi persoalan adalah delik ideologi di dalam KUHP hanya mengikat subjek tindak pidana yaitu "orang" sebagaimana tergambar dalam penggunaan frasa "barang siapa". ${ }^{33}$

48 Zaidan, M. A. (2015). Menuju Pembaruan Hukum Pidana. Jakarta: Sinar Grafika. p. 368

49 Mulyadi, L. (2013). Eksistensi Hukum Pidana Adat di Indonesia: Pengkajian Asas, Norma, Teori, Praktik dan Prosedurnya. Jurnal Hukum Dan Peradilan, 2(2), 225-246. https://doi.org/10.25216/jhp.2.2.2013.225-246 p. 233.

50 Lihat: Chazawi, A., \& Ferdian, A. (2018). Op.cit., p. 37-40. Jika penulis membandingkan dua buku yang ditulis oleh Adami Chazawi, beliau membedakan antara "objek perbuatan pidana" dengan "objek hukum tindak pidana", di mana objek hukum tindak pidana merupakan kepentingan hukum yang dilindungi oleh hukum pidana. Lihat: Chazawi, A. (2013). Op.cit. Hlml. 112. Sedangkan menurut penulis, objek perbuatan pidana merupakan unsur delik yang melekat/tidak dapat dipisahkan dengan unsur perbuatan.

51 Hiariej, E. O. . (2019). United Nations Convention Against Corruption dalam Sistem Hukum Indonesia. Mimbar Hukum - Fakultas Hukum Universitas Gadjah Mada, 31(1), 112-125. https://doi.org/10.22146/jmh.43968 p. 122.

52 Fajrin, Y. A., \& Triwijaya, A. F. (2019). Reconstruction of Castration Sanction Formulation in The Perspective of Indonesian Criminal Law Renewal. Jurnal Dinamika Hukum, 19(2), 389-406. https://doi.org/10.20884/1.jdh.2019.19.2.2469. p. 406.

53 Triwijaya, A. F., Fajrin, Y. A., \& Nurrahma, C. M. (2020). Dual Mediation: Penyelesaian Perkara Lingkungan Hidup yang Melibatkan Korporasi Sebagai Pelaku Melalui Pendekatan 
Menurut pandangan penulis, tingkat keberbahayaan delik ideologi ini (jika memperhatikan sejarah kelam bangsa Indonesia) adalah jika perbuatan tersebut dilakukan oleh kelompok/organ secara terorganisir, dan itu kecil sekali jika orang tunggal (sekalipun adanya penyertaan didalamnya) akan mampu untuk mewujudkan akibat berupa berkembang dan menyebarnya ajaran ideologi kiri tersebut.

Hukum pidana merupakan ultimum remidium atau obat terakhir dalam menyelesaikan suatu permasalahan hukum, karena perlu mengingat sifat dan ciri khas hukum pidana yang berupa penderitaan atau nestapa. Perkembangan hukum pidana saat ini pun semakin mengarah pada prinsip humanisasi hukum pidana, sehingga pemidanaan sudah tidak lagi ditujukan sebagai alat pembalasan (retributif), tetapi lebih mengarah kepada tujuan meresosialisasi dan merehabilitasi seorang pelaku kejahatan menjadi orang yang lebih baik lagi. ${ }^{54}$ Selain itu memperhatikan pula kondisi Sebagian besar lembaga pemasyarakatan di Indonesia yang sudah mencapai taraf over capacity, yang itu justru dapat menyebabkan kegagalan fungsi lembaga pemasyarakatan. ${ }^{55}$ Terlebih lagi atmosfer pembaruan hukum pidana Indonesia pun mengarah pada cita-cita perbaikan manusia Indonesia berdasar pada nilai-nilai Pancasila dan mengedepankan prinsip kemanusiaan dan keadilan/keseimbangan.

\subsection{Reformulasi Delik Ideologi Dalam Perspektif Pembaruan Hukum Pidana Nasional}

\subsubsection{Rumusan Delik Ideologi Dalam Rancangan KUHP draft Tahun 2019}

Pengaturan mengenai delik ideologi masih dipertahankan di dalam Rancangan KUHP Nasional (RKUHP), sehingga hal tersebut menggambarkan bahwa delik tersebut masih diporyeksikan untuk masuk dalam bagian hukum pidana nasional di masa mendatang. Delik ideologi di dalam RKUHP menggunakan terminologi "tindak pidana terhadap ideologi negara" yang masuk dalam Buku II tentang Tindak Pidana, di bagian Bab I tentang Tindak Pidana Terhadap Keamanan Negara (sama dengan tindak pidana makar dan tindak pidana terhadap pertahanan negara). Secara spesifik delik ideologi tersebut di atur di Pasal 188, Pasal 189 dan Pasal 190, yang isinya sebagai berikut:

\section{Pasal 188}

(1) Setiap Orang yang menyebarkan atau mengembangkan ajaran komunisme/marxisme-leninisme di muka umum dengan lisan atau tulisan termasuk menyebarkan atau mengembangkan melalui media apapun ....

(2) Dalam hal perbuatan sebagaimana dimaksud pada ayat (1) dilakukan dengan maksud mengubah atau mengganti Pancasila sebagai dasar negara...

(3) Dalam hal perbuatan sebagaimana dimaksud pada ayat (1) atau ayat (2) mengakibatkan terjadinya kerusuhan dalam masyarakat atau kerugian Harta Kekayaan ...

Restorative Justice. Udayana Master Law Journal, 9(2), 401-428. https://doi.org/10.14710/politika.3.2.2012. p. 405.

54 Fajrin, Y. A., \& Triwijaya, A. F. (2019). Op.cit. p 391.

55 Angkasa. (2010). Over Capacity Narapidana di Lembaga Pemasyarakatan, Faktor Penyebab, Implikasi Negatif, Serta Solusi. Jurnal Dinamika Hukum, 10(3), 213-221. https://doi.org/10.20884/1.jdh.2010.10.3.46. p. 214-215. 
(4) Dalam hal perbuatan sebagaimana dimaksud pada ayat (3) mengakibatkan orang menderita Luka Berat ....

(5) Dalam hal perbuatan sebagaimana dimaksud pada ayat (3) mengakibatkan matinya orang ...

(6) Tidak dipidana orang yang melakukan kajian terhadap ajaran komunisme/ marxisme-leninisme untuk kepentingan ilmu pengetahuan."

\section{Pasal 189}

Dipidana dengan pidana penjara paling lama 10 tahun, Setiap Orang yang:

a. mendirikan organisasi yang diketahui atau patut diduga menganut ajaran komunisme/marxisme-leninisme; atau

b. mengadakan hubungan dengan atau memberikan bantuan kepada atau menerima bantuan dari organisasi, baik di dalam maupun di luar negeri, yang sepatutnya diketahui menganut ajaran komunisme/marxisme leninisme dengan maksud mengubah dasar negara atau menggulingkan pemerintah yang sah."

\section{Pasal 190}

(1) Setiap Orang yang menyatakan keinginannya di muka umum dengan lisan, tulisan, atau melalui media apa pun untuk meniadakan atau mengganti Pancasila sebagai dasar negara ...

(2) Dalam hal perbuatan sebagaimana dimaksud pada ayat (1) mengakibatkan:

a. terjadinya kerusuhan dalam masyarakat atau timbulnya kerugian Harta Kekayaan ...

b. terjadinya kerusuhan dalam masyarakat yang mengakibatkan orang menderita Luka Berat .... ; atau

c. terjadinya kerusuhan dalam masyarakat yang mengakibatkan matinya orang ...."

Memperhatikan rumusan tersebut, secara substantif unsur perbuatan yang dilarang sebenarnya tidak jauh berbeda dengan apa yang diatur di dalam Undang-undang No. 27 Tahun 1999. Hal tersebut menggambarkan bahwa rumusan yang berlaku/ada saat ini, dipandang seluruhnya masih relevan untuk delik ideologi dalam KUHP Nasional di masa mendatang.

Ada beberapa tambahan dalam rancangan tersebut. Pertama, adanya penekanan mengenai pengecualian untuk perbuatan menyebarkan atau mengembangkan ideologi kiri di muka umum dengan lisan atau tulisan melalui media apapun, yaitu terdapat di Pasal 188 ayat (6). Pengecualian tersebut dapat dikualifikasikan sebagai salah satu alasan penghapus pidana, yaitu alasan pembenar, yang berarti bahwa perbuatan tersebut dibenarkan selama itu untuk kepentingan ilmu pengetahuan. ${ }^{56}$ Kedua, adanya penekanan mengenai pemberatan hukuman terhadap tiap-tiap akibat perbuatan, yaitu

56 Pada bagian Penjelasan Pasal 188 ayat (6) menerangkan bahwa yang dimaksud dengan "untuk kepentingan ilmu pengetahuan" misalnya "mengajar, mempelajari, memikirkan, menguji, dan menelaah di lembaga pendidikan atau lembaga penelitian dan pengkajian tanpa bermaksud untuk menyebarkan atau mengembangkan ajaran Komunisme/ MarxismeLeninisme". 
mengenai akibat luka berat dan kematian (Pasal 188 ayat (4) dan ayat (5), serta Pasal 190 ayat (2)). Selain kedua hal tersebut, secara substantif tidak berbeda jauh dengan rumusan yang ada sekarang, termasuk juga mengenai objek tindak pidana maupun mengenai penggunaan formeel delict dalam delik ideologi tersebut.

\subsubsection{Telaah Yuridis Rumusan Delik Ideologi di Dalam Rancangan KUHP Nasional}

Memperhatikan uraian pada bagian terdahulu dalam tulisan ini, maka terdapat dua hal yang akan ditelaah secara yuridis, yaitu pertama, mengenai keberadaan delik formil, dan kedua, mengenai objek delik ideologi tersebut. Mengenai dua hal tersebut akan penulis urai pada bagian berikut ini.

\section{1) Keberadaan formeel delict dalam delik ideologi}

Jika dibandingkan, Pasal 107a KUHP kembali diadopsi ke dalam Pasal 188 ayat (1) RKUHP, sebagaimana tersebut di atas. Kedua rumusan tersebut memang tidak secara ekplisit menegaskan (di dalam tubuh pasal maupun di bagian penjelasan pasalnya) mengenai bentuk delik formil. Tetapi jika menggunakan grammatical interpretation, rangkain kata yang dipakai hingga membetuk kalimat, "Setiap Orang yang menyebarkan atau mengembangkan ajaran komunisme/marxisme-leninisme di muka umum dengan lisan atau tulisan termasuk menyebarkan atau mengembangkan melalui media apapun", tidak mensyaratkan adanya akibat didalamnya. Sebab setelah kata kerja (unsur perbuatan "menyebarkan atau mengembangkan") kemudian diikuti oleh kata keterangan berupa "keterangan tempat" dan keterangan "cara yang digunakan", yaitu: "di muka umum dengan lisan atau tulisan termasuk menyebarkan atau mengembangkan melalui media apapun". Jika merupakan delik materiil, maka seharusnya dalam rumusan tersebut mencantumkan keterangan akibat dari perbuatan yang telah dilakukan. ${ }^{57}$ Mengenai selesainya perbuatan Pasal 188 ayat (1) RKUHP tersebut (maupun Pasal 107a KUHP), terletak pada selesainya perbuatan "menyebarkan" atau "mengembangkan". Rumusan bentuk delik formil pun ditemukan pula di dalam rumusan Pasal 188 ayat (2) RKUHP yang merupakan hasil adopsi dari Pasal 107d KUHP.

Menjadi persoalan adalah dalam RKUHP maupun KUHP tidak mendefinisikan apa yang dimaksud dengan perbuatan "menyebarkan" maupun "mengembangkan" ini. Definisi dalam Kamus Besar Bahasa Indonesia (KBBI) pun mengarah pada perbuatan lain (bisa penulis sebut sebagai sinonim kata), yang itu tidak menggambarkan mengenai bentuk konkrit perbuatan tersebut. ${ }^{58}$ Adami Chazawi

57 Bandingkan dengan unsur-unsur delik ideologi di Pasal 107a (dan juga Pasal 107d) yang diuraikan oleh Adami Chazawi. Unsur-unsur kedua pasal yang beliau uraikan tidak satu pun yang diposisikan ke dalam unsur akibar konstitutif sebagaimana yang beliau uraikan untuk unsur Pasal 107c. Lihat: Chazawi, A., \& Ferdian, A. (2018). Op.cit. p. 37-39.

58 KBBI mendefinisikan "menyebar" dengan berbagai arti, dan yang menurut penulis paling dekat pengertiannya dengan unsur perbuatan dalam delik ideologi ini adalah: "menyiarkan; membagi-bagikan; mengirimkan". Lihat: Badan Pengembangan dan Pembinaan Bahasa Kementerian Pendidikan dan Kebudayaan Republik Indonesia. (2020d). Arti Kata "menyebar." Retrieved from KBBI Daring website: https://kbbi.kemdikbud.go.id/entri/menyebar, diakses tanggal 8 Mei 2020. Sedangkan "mengembangkan" KBBI mendefinisikannya dengan: menjadikan besar (luas, merata, dan sebagainya); menjadikan maju (baik, sempurna, dan sebagainya). Lihat: Badan 
mengartikan perbuatan "menyebarkan" sebagai menyampaikan kepada orang banyak, sedangkan perbuatan "mengembangkan" sebagai menjadikan sesuatu bertambah banyak, bertambah sempurna/lengkap, dan berkembang dari keadaan semula. ${ }^{59}$ Menurut pandangan penulis dengan tafsir gramatikal, baik definisi dalam KBBI maupun sebagaimana yang dikemukakan oleh Adami Chazawi di atas, untuk perbuatan "menyebarkan" maupun "mengembangkan" haruslah ada syarat berupa akibat yang ditimbulkan, yaitu berupa tersebarnya atau berkembangnya ajaran ideologi kiri tersebut kepada orang lain. Persoalan berikutnya adalah, bagaimana membuktikan bahwa ideologi kiri tersebut telah tersebar dan telah berkembang? Atau, tersebar maupun berkembangnya ideologi kiri tersebut indikatornya apa? Jika dikolaborasikan dengan bentuk delik formil terhadap dua rumusan pasal tersebut, maka hal tersebut sangatlah berbahaya karena dapat dipakai untuk menjerat siapapun yang ditafsir/dipandang/dinilai telah melanggar perbuatan "menyebarkan" maupun "mengembangkan" ideologi tersebut.

Jika pembuat undang-undang ingin mempertahankan rumusan delik ideologi di pasal 188 ayat (1) maupun ayat (2) RKUHP tersebut serta mempertahankan delik formil didalamnya, maka seharusnya pembuat undang-undang membuat batasan mengenai perbuatan "menyebarkan" atau "mengembangkan" tersebut. Batasan tersebut haruslah secara konkrit dan objektif dapat diukur sesuai dengan tujuan keberadaan delik Pasal 188 ayat (1) dan ayat (2) tersebut, walau hal tersebut sangat lah sulit untuk dirumuskan.

\section{2) Objek delik ideologi.}

Terdapat dua objek dalam delik ideologi ini di dalam RKUHP, sama halnya dengan apa yang ada sekarang di dalam KUHP atau Undang-undang 27 Tahun 1999. Kedua objek delik tersebut yaitu: pertama, ajaran komunisme/marxisme-leninisme, dan kedua, segala bentuk ideologi yang ditujukan mengganti Pancasila. Objek kedua memang tidak secara eksplisit tertulis, baik di dalam KUHP maupun di dalam RKUHP. Tetapi penulis memberikan tafsir sebagai "segala bentuk ideologi" karena motif utama (dan mungkin satu-satunya) seseorang ingin mengganti Pancasila sebagaimana ketentuan Pasal 190 RKUHP maupun Pasal 107b KUHP adalah karena dalam alam berpikirnya, pelaku mempercayai dan menyakini bahwa ada yang lebih baik dari Pancasila sebagai dasar maupun ideologi negara. Sesuatu yang dipandang lebih baik menurut pelaku tersebut, pastilah merupakan ideologi atau ajaran lain selain Pancasila. Atas dasar itu lah penulis menggunakan terminologi "segala bentuk ideologi" sebagai objek delik ideologi bentuk kedua dala tulisan ini.

Khusus untuk objek delik ideologi yang pertama, yaitu mengenai ajaran komunisme/marxisme-leninisme (yang selanjutnya penulis sebut dengan ideologi kiri), antara RKUHP maupun KUHP (atau undang-undang 27 Tahun 1999) tidak terdapat perbedaan dalam penjelasannya. Keduanya mendefinisikan ideoologi kiri tersebut sebagai "paham atau ajaran Karl Mark yang terkait pada dasar-dasar dan taktik perjuangan yang diajarkan oleh Lenin, Stalin, Mao Tse Tung, dan lain-lain, mengandung

Pengembangan dan Pembinaan Bahasa Kementerian Pendidikan dan Kebudayaan Republik Indonesia. (2020c). Arti kata "Mengembangkan." Retrieved from KBBI Daring website: https://kbbi.kemdikbud.go.id/entri/mengembangkan, diakses tanggal 8 Mei 2020.

59 Lihat: Chazawi, A., \& Ferdian, A. (2018). Op.cit., p. 40. 
benih-benih dan unsur-unsur yang bertentangan dengan falsafah Pancasila". Persoalannya adalah, ajaran "Karl Mark, Lenin, Stalin, Mao Tse Tung" manakah yang dipandang bertentangan dengan Pancasila? Jika menggunakan tafsir gramatikal, maka frasa "mengandung benih-benih dan unsur-unsur yang bertentangan dengan falsafah Pancasila" tersebut itu bermakna syarat khusus, di mana "hanya" yang bertentangan dengan falsafah Pancasila saja lah yang tidak diperbolehkan. KBBI pun mendefinisikan "ajaran" sebagai nasihat; petuah; petunjuk, ${ }^{60}$ yang itu berarti tidak semua ajaran "Karl Mark, Lenin, Stalin, Mao Tse Tung" tersebut salah. Pembuat undang-undang perlu membuat batasan mengenai hal tersebut, yakni mengenai ajaran ideologi kiri mana kah yang dipandang bertentangan. Walaupun dalam merumuskan hal tersebut sulit, dan perlu usaha yang ekstra untuk merumuskan batasan tersebut.

Persoalan selanjutnya adalah mengenai terminologi "ajaran" yang muncul di dalam frasa "ajaran komunisme/marxisme-leninisme". Memperhatikan definisi "ajaran" di atas, maka ada keterkaitan antara "ajaran" sebagai "paham" dengan "ideologi". Menurut Ady Irawan dalam tesisnya menjelaskan bahwa tidak semua istilah faham itu dapat dikategorikan sebagai sebuah ideologi. ${ }^{61}$ Khusus untuk komunisme, marxisme, leninisme, Austin Ranny dan Franz Magnis Suseno menggolongkan ketiganya tidak hanya sebagai paham saja tetapi juga sebagai ideologi. ${ }^{62}$ Memperhatikan keterkaitan yang erat antara "ajaran" dengan "ideologi", maka tepatlah jika penulis menggunakan terminologi "delik ideologi" sebagai objek kajian dalam tulisan ini. Lalu timbul sebuah pertanyaan, apakah ideologi dapat menjadi objek delik?

Diketahui ideologi umumnya bersumber kepada aliran filsafat, ranah filsafat yang sifatnya abstrak dioperasionalkan melalui ideologi yang mana dapat dimaknai ideologi merupakan way of life atau pandangan hidup suatu negara. ${ }^{63}$ Terminologi "ideologi" di dalam KBBI diartikan dengan berbagai pengertian: pertama, sebagai kumpulan konsep bersistem yang dijadikan asas pendapat (kejadian) yang memberikan arah dan tujuan untuk kelangsungan hidup; kedua, cara berpikir seseorang atau suatu golongan; dan ketiga, paham, teori, dan tujuan yang merupakan satu program sosial politik. ${ }^{64}$ Penulis juga mengutip pendapat dari berbagai ahli/pakar mengenai "ideologi" tersebut. Menurut sejarah, istilah ideologi pertama kali dipakai pada tahun 1796 oleh Destutt de Tracy dengan konsep science

60 Lihat: Badan Pengembangan dan Pembinaan Bahasa Kementerian Pendidikan dan Kebudayaan Republik Indonesia. (2020a). Arti Kata "Ajaran." Retrieved from KBBI Daring website: https://kbbi.kemdikbud.go.id/entri/ajaran, diakses tanggal 8 Mei 2020.

61 Kata "faham" istilah lainnya adalah "aliran" yang dalam bahasa Inggris dikenal dengan kata "ism", sedangkan di Indonesia adanya penggunaan akhiran "-isme". Orang lebih sering menyebut istilah ini bersatu dengan faham yang dianutnya, misalnya Nasionalisme, Fasisme, Anarkhisme, Eksklusifisme, Liberalisme, Komunisme, Sosialisme dan sebagainya. Lihat: Irawan, A. (2012). Op.cit. p. 73.

62 Lihat: Suseno, F. M. (1992). Op.cit. p. 232

63 Widisuseno, I. (2014). Azas Filosofis Pancasila Sebagai Ideologi Dan Dasar Negara. Humanika, 20(2), 62-66. https://doi.org/10.14710/humanika.20.2.62-66. p. 64

64 Lihat: Badan Pengembangan dan Pembinaan Bahasa Kementerian Pendidikan dan Kebudayaan Republik Indonesia. (2020b). Arti Kata "Ideologi." Retrieved from KBBI Daring website: https://kbbi.kemdikbud.go.id/entri/ideologi, diakses tanggal 8 Mei 2020. 
of ideas guna membangun suatu sistem pengetahuan tentang cita-cita. ${ }^{65}$ Eagleton mendefinisikan ideologi dengan berbagai arti, diantaranya: ${ }^{66}$ sekumpulan ide atau pikiran dari sebuah kelompok atau kelas sosial yang memiliki karakteristik tertentu; atau serangkaian kepercayaan (beliefs) yang mendasari terhadap suatu tindakan. Franz Magnis Suseno ${ }^{67}$ membagi ideologi dalam tiga bentuk, yaitu pertama, sebagai kesadaran palsu yang dipakai oleh kalangan filosof dan ilmuwan sosial; kedua adalah ideologi dalam arti netral, di mana ideologi diidentifikasi sebagai keseluruhan sistem berpikir, nilai-nilai, dan sikap dasar suatu kelompok sosial atau kebudayaan tertentu; Ketiga, ideologi sebagai keyakinan yang tidak ilmiah, yang dipakai dalam filsafat dan ilmu-ilmu sosial yang positivistik. Karl Marx sendiri menjelaskan bahwa ideologi tidak menghasilkan pengetahuan yang bersifat objektif, melainkan subjektif. ${ }^{68} \mathrm{Al}$ Purwa Hadiwardoyo menjelaskan bahwa ideologi merupakan kumpulan ide-ide yang diyakini sebagai sangat bernilai dan karenanya juga dibela dan diperjuangkan dengan gigih oleh pendukungnya. ${ }^{69}$ Kaelan ketika menjelaskan mengenai ideologi tertutup pun menerangkan bahwa hal tersebut merupakan suatu sistem pemikiran tertutup..$^{70}$ Sebagaimana yang dikemukakan oleh Syamsul Arifin bahwa dari sejumlah definisi tentang ideologi bisa dipastikan kesemuanya itu memuat unsur/nilai idealisme. ${ }^{71}$

Penulis menerangkan banyak pendapat mengenai definisi ideologi tersebut guna menemukan sebuah pemahaman, bahwa ajaran atau ideologi tersebut merupakan sebuah sistem berpikir, gagasan, atau ide atau dapat pula disebut sebagai keyakinan

65 Sutikna, N. (2008). Ideologi Manusia Menurut Erich Fromm (Perpaduan Psikoanalisis Sigmund Freud Dan Kritik Sosial Karl Marx). Jurnal Filsafat, 18(2), 205-222. https://doi.org/10.22146/jf.3525. p. 207.

66 Dalam bukunya yang berjudul "ideology", Eagleton menjelaskan bahwa tidak seorangpun bisa memberikan satu definisi ideologi secara memadai. Selain definisi di atas, ideologi didefinisikan pula sebagai proses produksi berbagai makna, tanda/simbol dan nilai dalam kehidupan sosial; berbagai ide yang membantu melegitimasi dominasi kekuatan politik; atau media yang sangat penting bagi individu dalam menjalani hubungan dengan masyarakat dalam struktur sosial. Lihat: Irawan, A. (2012). Op.cit. p. 50.

67 Franz Magnis Suseno menjelaskan bahwa "ideologi sebagai kesadaran palsu merupakan teori-teori yang tidak berorientasi pada kebenaran, melainkan pada kepentingan pihak yang mempropagandakannya, sebagai sarana untuk melegitimasikan kekuasaannya. Ideologi dalam arti netral, ini terutama ditemukan dalam negara-negara yang menganggap penting adanya suatu ideologi negara. Disebut dalam arti netral karena baik buruknya tergantung kepada isi ideologi tersebut. Arti ketiga, ideologi sebagai keyakinan yang tidak ilmiah, biasanya digunakan dalam segala pemikiran yang tidak dapat dibuktikan secara logismatematis atau empiris, sehingga segala masalah etis dan moral, asumsi-asumsi normatif, dan pemikiran-pemikiran metafisis termasuk dalam wilayah ideologi". Lihat:: Suseno, F. M. (1992). Op.cit. p 230.

68 Frans Magnis Suseno, dalam Irawan, A. (2012). Op.cit. p. 54.

69 Ibid. p. 64.

70 Kaelan, dalam: Muslimin, H. (2016). Tantangan Terhadap Pancasila Sebagai Ideologi Dan Dasar Negara Pasca Reformasi. Jurnal Cakrawala Hukum, 7(1), 30-38. https://doi.org/10.26905/idjch.v7i1.1791. p. 33.

71 Syamsul Arifin, dalam: Irawan, A. (2012). Op.cit. p. 55. 
atau kepercayaan, yang kesemuanya itu masih bersifat subjektif. ${ }^{72}$ Maka dari itu, ideologi belum dapat dijadikan sebagai objek delik, apabila belum terwujud dalam suatu perbuatan yang memberikan impact negatif terhadap orang lain, masyarakat, atau negara. Jika dikaitkan dengan keberadaan delik formil dalam rumusan delik ideologi Pasal 188 ayat (1) dan (2) RKUHP dipandang oleh penulis hal tersebut telah melampaui batas/berlebihan serta cenderung dapat menciderai nilai-nilai kepastian, keadilan, dan kemanfaatan. Selain itu penulis juga berpendapat, bahwa jika mengacu pada TAP MPRS NO. XXV/ MPRS/1966, maka sejatinya yang menjadi objek persoalan adalah pada keberadaan PKI sebagai sebuah organisasi dan gerakannya, yang itu justru tidak muncul di KUHP maupun RKUHP Nasional. Artinya, terjadi pergeseran orientasi larangan yang semula dari larangan PKI organorgan sayapnya menuju larangan ideologi kiri secara umum, sehingga berakibat terhadap over penalisasi atau over action dari aparat di lapangan.

\subsubsection{Reformulasi Delik Ideologi Dalam Perspektif Pembaruan Hukum Pidana Nasional}

Pertanyaan mendasar dari politik hukum pidana (kebijakan hukum pidana/ penal policy) adalah, "apakah hukum positif yang berlaku (ius constitutum) sudah dirumuskan dengan baik?". Dalam menjawab pertanyaan tersebut, Barda Nawawi Arief mengemukakan hal tersebut akan terkait dengan aspek sosiopolitik, sosiofilosofis, dan sosiokultural ${ }^{73}$ Penyesuaian ini seringkali terjadi manakala suatu hukum positif telah berusia usang atau hukum positif hasil adopsi dari basis sosial yang berbeda. Fungsi penyesuaian tersebut sebagai upaya efektivitas bekerjanya hukum ditengah masyarakat, karena hukum yang tidak berfungsi merupakan kemunduran dan bentuk penurunan wibawa hukum. Kebijakan hukum pidana selain digali dari aspek nilai luhur bangsa, menurut Barda Nawai Arief perlu memperhatikan pula aspek perkembangan dunia internasional yang bermartabat. Termasuk merupakan perkembangan dunia internasional adalah pengakuan HAM yang didalamnya adalah kebebasan berfikir. Selain itu, politik hukum pidana nasional harus ditunjukkan kepada perlindungan masyarakat dari perilaku asosial yang berbahaya dan merugikan, serta untuk perbaikan pelaku menjadi individu yang lebih baik. ${ }^{74}$ Keberadaan nilai-nilai perlindungan masyarakat, khususnya dalam delik ideologi, juga tampak dari Naskah Akademik RKUHP yang disusun oleh Badan Pembinaan Hukum Nasional Kementerian Hukum dan Hak Asasi Manusia Republik Indonesia tahun 2015, yang menerangkan bahwa perbuatan terkait ideologi kiri merupakan tindak pidana, apabila menimbulkan akibat berupa terganggunya stabilitas di bidang politik dan keamanan (delik materil). ${ }^{75}$

72 Penulis mengidentifikasi bahwa ideologi bersifat subjektif, dalam bentuk ide atau keyakinan terhadap suatu nilai-nilai tertentu yang itu dapat membentuk sikap ke arah tujuan yang dicita-citakan, baik itu oleh individu, kelompok, masyarakat, maupun bangsa/negara.

73 Arief, B. N. (2011). Bunga Rampai Kebijakan Hukum Pidana: Perkembangan Penyusunan Konsep KUHP Baru (2nd ed.). Jakarta: Kencana. p. 29-30.

74 Barda Nawawi Arief, dalam: Suhariyono, A.R (2009). Op.cit. p. 627

75 Badan Pembinaan Hukum Nasional Kementerian Hukum dan Hak Asasi Manusia Republik Indonesia. (2015). Naskah Akademik RUU Tentang Kitab Undang-Undang Hukum Pidana (KUHP) Penyelarasan. Retrieved November 1, 2020, from Jaringan Dokumentasi Dan 
Apabila didalami makna tersebut nampak jika penal policy Indonesia muaranya adalah perlindungan masyarakat dari akibat berbahayanya suatu perbuatan/kejahatan, yang disebut sebagai upaya penanggulangan kejahatan. Beberapa kali PBB dalam kongresnya menekankan kepada negara-negara anggota untuk mengedepankan upaya pencegahan dalam menanggulangi kejahatan, diantaranya adalah Resolusi No. 3 dalam Kongres PBB ke-6 Tahun 1980, yang menjelaskan mengenai pentingnya penekanan aspek kesehatan jiwa masyarakat (that crime prevention strategies should be based on exalting the spirit of man and reinforcing his faith in his ability to do good). ${ }^{76}$ Sehingga keberadaan delik formil memiliki dasar justifikasi di sini, yaitu sebagai sarana mencegah kejahatan tanpa harus menunggu kejahatan itu terjadi dan menimbulkan akibat. Tetapi yang perlu untuk diingat bahwa penanggulangan kejahatan dapat dilakukan tidak semata melalui sarana penal tetapi juga melalui sarana non penal, sebagaimana yang dikemukakan G.P. Hoefnagels. ${ }^{77}$ Terlebih lagi jika berkaitan dengan delik ideologi sebagaimana yang dimaksud dalam tulisan ini, perlu mengedepankan upaya-upaya penanggulangan melalui sarana non penal. Hal ini pun berkaitan dengan objek delik ideologi ini, yaitu sistem berpikir, gagasan, atau ide atau dapat pula disebut sebagai keyakinan atau kepercayaan. Selama ideologi kiri tersebut belum diaktualisasikan dalam wujud perbuatan konkrit yang merugikan kepentingan negara dan masyarakat, maka tidak lah seharusnya digunakan pendekatan penal. Menjadi penting rasanya peran pendidikan sebagai sarana menjernihkan, meluruskan, pemahaman/ideologi seseorang yang kontra dengan ideologi Pancasila. Jika penulis menggunakan perbandingan, bisa dilihat dari adanya upaya deradikalisasi terhadap para pelanggar delik terorisme. ${ }^{78}$ Pendekatan non penal dalam upaya pencegahan kejahatan pun selaras dengan arah penal policy yang terkandung di dalam RKUHP Nasional. Perumusan beberapa pasal delik ideologi (Pasal 107a KUHP maupun Pasal 188 ayat (1) RKUHP 2019) dalam bentuk delik formil, dipandang oleh penulis sudah tidak diperlukan. Mengingat pula RKUHP (dan KUHP saat ini) masing mengenal adanya aanslag sebagai bentuk delik formil, yang mana dapat direformulasi hingga mampu menyentuh perkara ideologi.

Guna mendukung cita-cita pembaruan hukum pidana nasional, maka diperlukan upaya yang selektif dan cermat dalam mengkriminalisasikan suatu perbuatan hingga menjadi suatu delik pidana di dalam RKUHP maupun peraturan perundang-undangan lainnya. Sebab ketidakcermatan dalam mengkriminalisasikan suatu perbuatan, dapat berimplikasi terhadap krisis kelebihan kriminalisasi (the crisis of overcriminalization), dan krisis pelampauan batas hukum pidana (the crisis of overreach of the criminal law). ${ }^{79}$ Sebagaimana yang telah penulis urai di bagian sebelumnya mengenai unsur perbuatan "menyebarkan" dan "mengembangkan" pada Pasal 107 a (maupun Pasal 188 ayat (1) RKUHP 2019), maka kedua perbuatan tersebut masih dipandang sebagai perbuatan yang masih sangat abstrak dan dapat diinterpretasikan secara subjektif, sehingga rentan

\footnotetext{
Informasi Hukum Badan Pembinaan Hukum Nasional website: https://bphn.jdihn.go.id/dokumen/view?id=38698. P. 211.

76 Arief, B. N. (2011). Op.cit. p. 50-51

77 Ibid. p. 45.

78 Isnanto, S. H. (2015). Berbagai Masalah dan Tantangan Radikalisasi Dan Deradikalisasi Terorisme di Indonesia. Jurnal Pertahanan $\mathcal{E}$ Bela Negara, 5(2), 225-244. https://doi.org/10.33172/jpbh.v5i2.366.

79 Suhariyanto, B. (2012). Menuntut Akuntabilitas Putusan Pengadilan Melalui Pemidanaan Terhadap Hakim. Jurnal Hukum Dan Peradilan, 1(2). https://doi.org/10.25216/jhp.1.2.2012.249-274. p. 266.
} 
untuk dipakai memidana seseorang. Maka dari itu, kiranya kedua unsur perbutan tersebut dihilangkan dan menggantinya dengan unsur yang lebih konkrit, semisal "menggunakan atribut atau simbol PKI sebagai bentuk dukungan terhadapnya". Jika tetap dipertahankan kedua unsur perbuatan tersebut, maka perlu diberikan batasanbatasannya sebagaimana yang penulis urai di atas. Begitu juga mengenai objek delik ideologi, khususnya mengenai objek ajaran komunisme/marxisme-leninisme. Perlu ada batasan hingga jelas mengenai: sub ajaran manakah (dari ketiga ideologi tersebut) yang dipandang bertentangan dengan Pancasila. Mengenai kejelasan rumusan dalam hukum pidana, Jan Remmelink mengingatkan keberadaan asas lex certa atau bestimmtheitsgebot yang bemakna bahwa setiap perbuatan yang dilanggar dan kerugiannya harus lah jelas. ${ }^{80}$ Penulis juga mengingatkan, bahwa keberadaan delik ideologi ini didasarkan pada histori kelam bangsa Indonesia akibat pemberontakan PKI. Justru frasa "PKI" hilang dari rumusan delik ideologi, dan diperluas menjadi ajaran komunisme/marxisme-leninisme.

Jan Gijssels dan Mark van Hoecke menerangkan bahwa "hukum merupakan suatu pencerminan dari suatu peradaban (beschaving)", ${ }^{81}$ sehingga hukum di Indonesia (termasuk hukum pidana) haruslah menjadi perwujudan nilai-nilai kemanusiaan yang adil dan beradab sebagaimana yang diamanahkan oleh Pancasila. Maka dalam upaya mempertahankan eksistensi Pancasila sebagai ideologi Bangsa Indonesia, harus dilakukan dengan upaya yang beradab sebagai cerminan manusia Indonesia atau manusia Pancasila. Sebab sebagai ideologi terbuka Pancasila tidak lah hanya berisi ideide yang diawang-awang (utopis), namun bersifat realistis yang dapat dijabarkan dalam kehidupan nyata dalam berbagai bidang kehidupan, termasuk di bidang penanggulangan kejahatan. ${ }^{82}$ Jika dikaitkan dengan pendapat Barda Nawawi Arief mengenai pembangunan hukum nasional melalui berbagai pendekatan, ${ }^{83}$ maka pencegahan menyebarnya ideologi yang dipandang merongrong NKRI dan Pancasila, dapat dilakukan dengan pendekatan moral ketuhanan maupun pendekatan kemanusiaan. Memperhatikan hal tersebut maka sinkronlah dengan apa yang dianjurkan oleh PBB mengenai penguatan aspek kesehatan jiwa masyarakat, yang oleh penulis sebut dengan upaya melalui sarana pendidikan. ${ }^{84}$

Terakhir adalah pendapat Dirk Merckx ${ }^{85}$ mengenai tahapan penentuan sanksi/aturan pidana (maupun dalam mereformulasinya). Salah satunya, sekaligus merupakan tahapan yang paling mendasar, adalah tahapan pengumpulan informasi tentang fenomena kriminalitas dan ancamannya pada masyarakat (Gathering knowledge and

so Iksan, M. (2017). Asas Legalitas Dalam Hukum Pidana: Studi Komparatif Asas Legalitas Hukum Pidana Indonesia Dan Hukum Pidana Islam (Jinayah). Serambi Hukum, 11(1), 1-26. p. 9

81 Dalam: Marbun, R. (2017). Op.cit. p. 541.

82 Kaelan, dalam Muslimin, H. (2016). Op.cit. p. 34

83 Fatoni, S. (2015). Pembaruan Hukum Pidana Melalui Aktualisasi Nilai-Nilai Pancasila Berorientasikan Pendekatan Religius. Ahkam: Jurnal Hukum Islam, 3(1), 43-66. https://doi.org/10.21274/ahkam.2015.3.1.41-64. p. 46

84 Sama halnya dengan pendapat dari Harianto Dajnggih. Lihat: Djanggih, H. (2013). Kebijakan Penanggulangan Kejahatan Terhadap Pancasila Sebagai Ideologi Negara. Jurnal Media Hukum, 1(1), 25-34. p. 33

85 Dirk Merckx sebagaimana dikutip oleh Mardjono Reksodiputro. Lihat: Irawan, A. (2012). Op.cit. p. 29. 
information on crime phenomena and their social impact and threat). Pada tahapan ini perumus undang-undang perlu untuk menelaah secara cermat fenomena kejahatan ideologi ini, khususnya terkait Pasal 107a KUHP yang masih diadopsi oleh Pasal 188 ayat (1) RKUHP 2019. Sebagaimana data yang telah penulis kemukakan di atas, bahwa dalam rentang tahun 2012 s/d 2019 'hanya' terdapat empat buah perkara yang diputus dengan Pasal 107a KUHP ini. Jumlah kasus tersebut patut menjadi renungan, "masihkah kita memerlukan keberadaan ketentuan Pasal 188 (1) RKUHP?". Lalu, apakah sanksi yang diberikan kepada para pelanggar tersebut mampu memberikan dampak positif terhadap para terhukum sebagaimana tujuan pemidanaan yang dicita-citakan di dalam RKUHP (pemidanaan bertujuan memasyarakatkan terpidana dengan pembinaan dan pembimbingan agar menjadi orang yang baik dan berguna), atau justru cap/label sebagai mantan terpidana akan memberikan dampak negatif dalam kehidupan sosial mereka dengan masyarakat. Mengingat keberadaan PKI (sebagai sejarah kelam bangsa Indonesia) maupun ideologi-ideologi lain yang mengancam eksistensi Pancasila maupun NKRI merupakan sesuatu yang nyata (tidak terbatas hanya kepada ideologi kiri, tetapi juga ideologi-ideologi lainnya seperti liberalisme, kapitaslisme, dsb), maka penulis berpandangan bahwa keberadaan delik ideologi ini masih diperlukan di dalam KUHP Nasional di masa yang akan datang, tetapi diperlukan telaah secara cermat, komprehensif dan mendalam guna menemukan sebuah rumusan delik ideologi yang mencerminkan Pancasila sebagai ideologi bangsa Indonesia.

\section{Kesimpulan}

Eksistensi delik ideologi terdapat dalam beberapa peraturan perundang-undangan yaitu KUHP, Undang-undang Partai Politik, dan Undang-undang Ormas. Eksistensi delik ideologi menimbulkan problematika yuridis sehingga rentan disalahgunakan. Hal tersebut sebagai akibat dari adanya bentuk delik formil di Pasal 107a dan Pasal 107d . Keberadaan delik formil untuk delik ideologi tersebut sejatinya tidak diperlukan, mengingat tingkat berbahaya/ancaman terhadap ideologi negara maupun keamanan maupun kesatuan negara baru muncul ketika ideologi menyimpang ini telah diwujudkan dalam suatu struktur atau organisasi. Maka keberadaan delik ideologi di masa yang akan datang perlu untuk disinergikan dengan ketentuan mengenai makar/aanslag yang notabene menganut bentuk delik formil. Selain mengenai keberadaan delik formil, yang menjadi persoalan di dalam rumusan delik ideologi adalah mengenai objek tindak pidana, yaitu mengenai ideologi terlarang berupa komunisme/marxisme-leninisme. Perlu ada batasan yang jelas mengenai objek tindak pidana ideologi ini, sebab ideologi sendiri merupakan bentuk pemikiran seseorang yang bersifat subjektif yang sulit untuk dibuktikan. Terlebih ancaman untuk Indonesia sebagai negara maupun sebagai bangsa saat ini maupun di masa mendatang, tidak hanya dari ideologi komunisme/marxisme-leninisme semata melainkan juga ideologiideologi lainnya tidak terkecuali adalah ideologi liberalisme dengan kapitalismenya. Sebagai bagian dari wajah dari pembaruan hukum pidana nasional, maka perlu memperhatikan sarana-sarana non penal dalam mencegah maupun menanggulangi delik-delik ideologi ini, misalnya melalui upaya pendidikan dan pemahaman bagi pihak-pihak yang berpotensi menyebarkan maupun menjadi korban penyebaran ideologi-ideologi yang mengancam eksistensi Pancasila sebagai ideologi bangsa Indonesia. 


\section{Daftar Pustaka / Daftar Referensi}

\section{$\underline{\text { Buku }}$}

Arief, B. N. (2011). Bunga Rampai Kebijakan Hukum Pidana: Perkembangan Penyusunan Konsep KUHP Baru (2nd ed.). Jakarta: Kencana.

Chazawi, A., \& Ferdian, A. (2018). Kejahatan Terhadap Negara Kesatuan Republik Indonesia. Jakarta: Sinar Grafika.

Lamintang, P. A. F. (2013). Dasar-dasar Hukum Pidana Indonesia. Bandung: Citra Aditya Bakti.

Suseno, F. M. (1992). Filsafat Sebagai Ilmu Kritis. Yogyakarta: Kanisius.

Zaidan, M. A. (2015). Menuju Pembaruan Hukum Pidana. Jakarta: Sinar Grafika.

\section{Jurnal}

Agustian, R. A. (2011). Tindak Pidana Terhadap Keamanan Negara Dalam Perspektif Delik Politik di Indonesia. Masalah-Masalah Hukum, 40(3), 344-348. https:// doi.org/10.14710/mmh.40.3.2011.344-348.

Angkasa. (2010). Over Capacity Narapidana di Lembaga Pemasyarakatan, Faktor Penyebab, Implikasi Negatif, Serta Solusi. Jurnal Dinamika Hukum, 10(3), 213-221. https:// doi.org/10.20884/1.jdh.2010.10.3.46.

Azizah, N. (2019). Islamisme: Ideologi Gerakan Kahar Mudzakkar di Sulawesi Selatan 1952-1965. Jurnal Penelitian Keislaman, 15(2), 95-104. https:// doi.org/10.20414/jpk.v15i2.1585.

Djanggih, H. (2013). Kebijakan Penanggulangan Kejahatan Terhadap Pancasila Sebagai Ideologi Negara. Jurnal Media Hukum, 1(1), 25-34.

Fajrin, Y. A., \& Triwijaya, A. F. (2019). Reconstruction of Castration Sanction Formulation in The Perspective of Indonesian Criminal Law Renewal. Jurnal Dinamika Hukum, 19(2), 389-406. https:/ / doi.org/10.20884/1.jdh.2019.19.2.2469.

Fatoni, S. (2015). Pembaruan Hukum Pidana Melalui Aktualisasi Nilai-Nilai Pancasila Berorientasikan Pendekatan Religius. Ahkam: Jurnal Hukum Islam, 3(1), 43-66. https:// doi.org/10.21274/ahkam.2015.3.1.41-64.

Hamzah, A. (2000). Tindak Pidana Terhadap Proses Kehidupan Ketatanegaraan Dalam Rancangan KUHP Baru. Aliansi Nasional Reformasi KUHP, 1-6.

Hiariej, E. O. (2019). United Nations Convention Against Corruption dalam Sistem Hukum Indonesia. Mimbar Hukum - Fakultas Hukum Universitas Gadjah Mada, 31(1), 112-125. https:// doi.org/10.22146/jmh.43968 
Iksan, M. (2017). Asas Legalitas Dalam Hukum Pidana: Studi Komparatif Asas Legalitas Hukum Pidana Indonesia Dan Hukum Pidana Islam (Jinayah). Serambi Hukum, 11(1), 1-26.

Isnanto, S. H. (2015). Berbagai Masalah dan Tantangan Radikalisasi dan Deradikalisasi Terorisme di Indonesia. Jurnal Pertahanan \& Bela Negara, 5(2), 225-244. https:// doi.org/10.33172/jpbh.v5i2.366.

Mafud MD, M. (2018). Membangun Jati Diri Bangsa: Globalisasi sebagai Tantangan dan Pancasila sebagai Imperatif Solusi. Sabda, 13(2), 145-153. https:// doi.org/10.14710/sabda.13.2.145-153.

Marbun, R. (2017). Diskursus Perumusan Ideologi Sebagai Perbuatan Pidana dalam Rancangan Kitab Undang-Undang Hukum Pidana 2015. Padjajaran Jurnal Ilmu Hukum, 4(3), 532-550. https:// doi.org/10.22304/pjih.v4n3.a6.

Muslimin, H. (2016). Tantangan Terhadap Pancasila Sebagai Ideologi dan Dasar Negara Pasca Reformasi. Jurnal Cakrawala Hukum, 7(1), 30-38. https://doi.org/10.26905/idjch.v7i1.1791

Maulida, F. H. (2018). Hitam Putih PRRI-Permesta: Konvergensi Dua Kepentingan Berbeda 1956-1961. Paradigma: Jurnal Kajian Budaya, 8(2), 174. https:// doi.org/10.17510/paradigma.v8i2.180.

Mulyadi, L. (2013). Eksistensi Hukum Pidana Adat di Indonesia: Pengkajian Asas, Norma, Teori, Praktik dan Prosedurnya. Jurnal Hukum Dan Peradilan, 2(2), 225-246. https:// doi.org/10.25216/jhp.2.2.2013.225-246

Purba, A., \& Wijaya, F. (2019). Analisis Putusan Nomor 559/Pid.B/2017/Pn.Byw. Pengadilan Negeri Banyuwangi Tentang Penyebaran Ajaran Komunisme/Marxisme-Leninisme Secara Melawan Hukum Berdasarkan Pasal 107a KUHP. Jurnal Hukum Adigama, 2(3), 1-22. https://doi.org/10.24912/adigama.v2i2.6907.

Subhan, M. (2019). Perlindungan Hukum Bagi Penganut Ideologi Komunisme/Marxisme-Leninisme di Indonesia. Mimbar Keadilan, 12(2), 138-154. https:// doi.org/10.30996/mk.v12i2.2385.

Suhariyanto, B. (2012). Menuntut Akuntabilitas Putusan Pengadilan Melalui Pemidanaan Terhadap Hakim. Jurnal Hukum Dan Peradilan, 1(2). https:// doi.org/10.25216/jhp.1.2.2012.249-274.

Suhariyono, A.R (2009). Penentuan Sanksi Pidana Dalam Suatu Undang-Undang. Legislasi Indonesia, 6(4), 615-666.

Sutikna, N. (2008). Ideologi Manusia Menurut Erich Fromm (Perpaduan Psikoanalisis Sigmund Freud Dan Kritik Sosial Karl Marx). Jurnal Filsafat, 18(2), 205-222. https:// doi.org/10.22146/jf.3525. 
Triwijaya, A. F., Fajrin, Y. A., \& Wibowo, A. P. (2020). Quo Vadis: Pancasila Sebagai Jiwa Hukum Indonesia. Jurnal Pendidikan PKN (Pancasila Dan Kewarganegaraan), 1(2), 115-129. https:// doi.org/10.26418/jppkn.v1i2.41083.

Triwijaya, A. F., Fajrin, Y. A., \& Nurrahma, C. M. (2020). Dual Mediation: Penyelesaian Perkara Lingkungan Hidup yang Melibatkan Korporasi Sebagai Pelaku Melalui Pendekatan Restorative Justice. Udayana Master Law Journal, 9(2), 401-428. https:// doi.org/10.14710/politika.3.2.2012.

Usman. (2015). Negara dan Fungsinya (Telaah atas Pemikiran Politik). Al-Daulah, 4(1), 130-139. https:// doi.org/10.24252/ad.v4i1.1506.

Wibowo, A. (2013). Kebijakan Kriminalisasi Delik Pencemaran Nama Baik di Indonesia. Pandecta: Research Law Journal, 7(1). https://doi.org/10.15294/pandecta.v7i1.2358

Widisuseno, I. (2014). Azas Filosofis Pancasila Sebagai Ideologi Dan Dasar Negara. Humanika, 20(2), 62-66. https:/ / doi.org/10.14710/humanika.20.2.62-66.

\section{$\underline{\text { Tesis }}$}

Irawan, A. (2012). Kebijakan Formulatif Hukum Pidana Tentang Kriminalisasi Ideologi Komunisme / Marxisme - Leninisme Sebagai Kejahatan Terhadap Keamanan Negara Dalam Undang-Undang Nomor 27 Tahun 1999 Tentang Perubahan KUHP Yang Berkaitan Dengan Kejahatan Terhadap Keamanan Negara. Tesis. Yogyakarta: Universitas Islam Indonesia.

Aminuddin, M.Z. (2006). Kebijakan Legislatif Dalam Rangka Perlindungan Ideologi Dan Konstitusi Negara Dengan Hukum Pidana. Tesis. Semarang: Universitas Diponegoro

Simanjuntak, A. (2003). Delik Penyebaran atau Pengembangan Komunisme/MarxismeLeninisme Dikaitkan Dengan Hak Atas Kebebasan Berpendapat. Tesis. Surabaya: Universitas Airlangga.

\section{Online/World Wide Web:}

Badan Pembinaan Hukum Nasional Kementerian Hukum dan Hak Asasi Manusia Republik Indonesia. (2015). Naskah Akademik RUU Tentang Kitab UndangUndang Hukum Pidana (KUHP) Penyelarasan. Retrieved November 1, 2020, from Jaringan Dokumentasi Dan Informasi Hukum Badan Pembinaan Hukum Nasional website: https://bphn.jdihn.go.id/dokumen/view?id=38698, diakses tanggal 8 Mei 2020

Badan Pengembangan dan Pembinaan Bahasa Kementerian Pendidikan dan Kebudayaan Republik Indonesia. (2020). KBBI Daring website: https://kbbi.kemdikbud.go.id, diakses tanggal 8 Mei 2020.

Mahkamah Agung Republik Indonesia. (n.d.). Direktori Putusan: Publikasi Dokumen Elektronik Putusan Seluruh Pengadilan Di Indonesia. Retrieved July 3, 2020, from Direktori Putusan Mahkamah Agung Republik Indonesia website: https:// putusan3.mahkamahagung.go.id/, diakses tanggal 8 Mei 2020 
P-ISSN: 0215-899X, E-ISSN: 2579-9487

\section{Lain-lain:}

Asshiddiqie, J. (2008). Ideologi, Pancasila, dan konstitusi. Mahkamah Konstitusi Republik Indonesia, (1), 1-23. 